This manuscript is a preprint and has been formally accepted for publication in

Basin Research 


\section{Base-Salt Relief Controls Salt-Related Deformation 4 in the Outer Kwanza Basin, offshore Angola}

5 Sian L. Evans*, Christopher A.-L. Jackson

6 Basins Research Group (BRG), Department of Earth Science \& Engineering, Imperial College, Prince Consort Road,

7 London, SW72BP, United Kingdom

$8 \quad$ *sian.evans15@imperial.ac.uk 
Abstract

Salt-influenced passive margins are widespread and commonly hydrocarbon-rich. However, they can be structurally complex, with their kinematic development being poorly understood. Classic models of salt tectonics divide such margins into updip extensional, mid-slope translational, and downdip contractional kinematic domains. Furthermore the faults, folds, and salt walls associated with each kinematic domain are typically assumed to form perpendicular to the maximum principal stress, which in gravitationally driven systems means broadly perpendicular to base salt dip. We use high-resolution 3D seismic reflection data from the Outer Kwanza Basin, offshore Angola to show that these models cannot explain the diversity of salt structures developing on passive margins, especially those defined by considerable relief on the base-ofsalt surface.

Overburden seismic-stratigraphic patterns record the basinward translation and rotation, allowing us to reconstruct the origin and evolution of the salt structures. We show structures in the transitional domain of the Outer Kwanza Basin display three dominant trends, each characterised by different structural styles: i) salt walls perpendicular to the overall base salt dip, ii) salt walls parallel to the base salt dip, and iii) salt walls oblique to the base salt dip.

We show that each set of walls has a unique history, with synchronous phases of extension and compression occurring in adjacent structures despite their close spatial relationship. Our analysis suggests that, in the Outer Kwanza Basin, the structural evolution of the salt and overburden is predominantly controlled by translation over relief on the base-salt surface formed above fault scarps associated with a preceding phase of rifting.

Changes in the downdip volumetric flux and velocity of the salt over topographic features can cause local extension or contraction of the salt and its overburden, associated with local acceleration or deceleration of the salt, respectively. This interaction with base-salt relief creates locally variable stress fields that deform the salt and its overburden, overprinting the broader, margin-scale salt tectonics typically associated with gravity gliding and spreading. 


\section{Introduction}

\subsection{Passive margin salt-tectonics}

37 There are two end-member models of gravity-driven salt tectonics on passive margins; 'gravity

38 gliding', which occurs due to seaward tilting of the margin during continental uplift and basin 39 subsidence, and 'gravity spreading', which occurs due to differential loading of the margin, 40 principally by subsalt sediments eroded and shed from the rising continent (Jackson et al., 1994;

41 Schultz-Ela, 2001; Fort et al. 2004; Hudec and Jackson, 2004; Brun and Fort, 2011; Peel, 2014).

42 Salt-influenced passive margins dominated by gravity gliding (e.g. offshore Israel, eastern 43 Mediterranean) are typically divided into broad, kinematically-linked zones of updip extension, 44 mid-slope translation and downdip contraction (Figure 1)). Each zone is associated with a distinct 45 suite of structures within the salt and its overburden. The updip extensional zone is commonly 46 associated with salt-detached normal faults, salt rollers, rafts, graben and turtles, whereas the 47 downdip contractional zone is associated with salt-cored anticlines and thrusts (Brun and Fort, 48 2011). In both zones, the long-axes of these structures are subparallel to the strike of the margin, 49 reflecting their formation perpendicular to the maximum principal stress, which is aligned in the 50 direction of the base-salt dip.

51 Similar structures and trends characterize margins dominated by gravity-spreading (e.g. Nile 52 Delta, eastern Mediterranean), which are also divided into kinematic zones of lateral extension 53 within the proximal part of the load and contraction near the distal pinchout of the load. 54 However, in these cases the orientation of the extensional and contractional structures will be 55 determined by the geometry of the load. For example, in the case of a delta prograding out into 56 a basin containing salt, the fold-and-thrust belt will be arcuate, thus mimicking the arcuate 57 geometry of the delta front (Figure 1). Both the gravity gliding and spreading models typically 58 envisage a smoothly seaward-dipping base-salt, despite the fact that many salt basins formed 59 above substantial, pre- or syn-depositional structural relief (e.g. Rowan, 2012; Dooley et al., 2017; 60 Dooley et al. 2018). 


\subsection{Influence of Base-Salt Relief on Gravity-Driven Deformation}

62 Over geological timescales, the rheological behaviour of salt can be approximated as highly 63 viscous fluid (Weijermars et al., 1993). Fluids such as these are responsive to the geometry of the 64 surface they flow across, and since salt can be deposited shortly after rifting, the base-salt surface

65 is commonly rugose at varying scales (e.g. Hudec et al. 2013). Physical and numerical analogue models, as well as observations from seismically imaged passive margins, show that gravity

67 gliding and the otherwise free seaward flow of salt may be complicated by residual topography on the base-salt surface. Underlying fault scarps or folds can both create an uneven base-salt surface with which the salt interacts as it flows basinward.

For example, Gaullier et al. (1993) use physical analogue models to simulate salt flow over basesalt steps related to relict syn-rift fault scarps. Base-salt steps oblique to the overall gliding

72 direction generate oblique faults in the overburden, demonstrating a strong correlation between

73 structural trends below the salt décollement and those in the overburden. Cobbold and Szatmari

74 (1991) and Tadeu dos Reis et al. (2008) also use physical models, in the latter case supported by 75 natural examples from the western Mediterranean Gulf of Lion, to show how local changes in the base-salt dip direction can locally redirect salt flow. More specifically, they show that convex and concave base-salt surfaces can generate bi-directional or radial gliding patterns. Concave geometries lead to convergent salt flow that can generate compressional structures, whereas convex geometries lead to divergent salt flow that can generate extensional structures.

More recently, Dooley et al. (2017) (see also Dooley et al., 2018) further investigate salt flow over

81 downflow- and upflow-facing steps in the base-salt, showing that the change in salt flux over a

82 step can be associated with local acceleration and deceleration (Figure 2). The ratio of initial salt

83 thickness to the height of step is important as this controls the change in flux across the step, and

84 the contribution of basal drag is greater for thin salt (Figure $2 b$ and $2 d$ ) vs. thick salt (Figure 2a

85 and $2 c$ ). In the case of a downflow-facing step, these spatial changes in salt flux can generate an 86 extensional hinge at the top of the step, and a contractional hinge at the base (Figure 2d). Further 87 complexity arises when we consider that local stress fields may vary through time as a function 88 of the net seaward salt flow. For example, Dooley et al. (2017) show that as salt contracts at the 
89 top of an upflow-facing ramp (Figure $2 \mathrm{~b}$ ), it thickens and gradually allows the salt velocity to 90 increase, which results in overburden extension. However, the reactive or passive diapir that

91 forms in this position may then be squeezed as it translates seaward and later passes through 92 the contractional hinge of another step. Salt structures and their overburden may thus go 93 through multiple phases of extension and contraction, with these local changes in stress fields 94 overprinting the margin-scale kinematic zones associated with classic models of gravity gliding 95 and spreading (Dooley et al. 2018) (Figure 1). These studies show the significant impact base-salt 96 relief can have on the structural evolution of salt-influenced passive margins. More specifically, 97 they show that extension and contraction can occur anywhere on a passive margin, and that 98 structures may develop oblique to the regional dip, more closely mimicking the trend of features 99 on the base-salt surface which influence their growth. There are, however, relatively few natural 100 examples showing how base salt relief can control salt flow and supra-salt deformation patterns.

101 High-quality 3D seismic reflection data from the Kwanza Basin, offshore Angola, provides us with 102 an opportunity to assess the salt-tectonic development of an area defined by significant base103 salt relief. We first characterize the large-scale structure and kinematics of the study area, before 104 focusing in on the development of individual structures during basinward translation of the salt 105 and its overburden. By analysing and interpreting structural and stratigraphic relationships in the 106 overburden, we are able to reconstruct the origin and growth of salt structures. In doing so, we 107 highlight the important role of base-salt relief in controlling the patterns and products of salt flow 108 during passive margin development, and the overall structural evolution of the basin. These data 109 support the observations from physical models discussed above that the widely accepted and 110 applied gravity gliding/spreading models envisaging broad, margin-scale kinematic zones (Figure 111 1) do not fully capture the variety of structural styles and orientations of salt structures present 112 on many salt-influenced passive margins. Although based on observations from the Kwanza 113 Basin, the implications of the study are likely applicable to other salt-influenced basins and 114 passive margins defined by significant base-salt relief. 


\section{Geological setting}

116 The Kwanza Basin forms part of the salt-influenced passive margin characterising much of 117 offshore Angola (Evans, 1978). The basin is $>300 \mathrm{~km}$ wide, stretching from onshore exposures in 118 the Precambrian Congo Craton westwards to the abyssal plain (Hudec and Jackson, 2004). The 119 southern margin of the basin is marked by a line of seamounts and volcanic rocks that separate 120 the Kwanza Basin from the Benguela Basin. The northern margin of the basin is poorly defined, 121 with the Kwanza Basin passing gradually into the Lower Congo Basin.

122 Rifting of the Kwanza Basin initiated in the Early Cretaceous, associated with the opening of the 123 South Atlantic Ocean during breakup of the supercontinent Gondwana (Brice et al., 1982). A thick 124 layer (locally up to $4 \mathrm{~km}$; Hudec and Jackson, 2004) of Aptian salt was deposited shortly after 125 rifting, draping the residual syn-rift relief. The salt was deposited in two sub-basins separated by 126 a margin-parallel chain of platforms, known as the Atlantic hinge zone, where salt is thin or 127 absent (Figure 3b) (Brink, 1974; Hudec and Jackson, 2004). The sub-basins are termed the Inner

128 (eastern and landward) and Outer (western and seaward) Kwanza Basins. Analogous salt basins 129 are present across the Atlantic on the conjugate South American margin (Evans, 1978; Quirk et 130 al., 2012).

131 Since the deposition of the Aptian salt, salt tectonics have dominated the tectono-stratigraphic 132 evolution of the Kwanza Basin (Marton et al., 2000). Hudec and Jackson (2004) interpreted key 133 structures on a regional 2D seismic line, and defined the updip extensional and downdip 134 contractional domains (Figure 3a, location shown in Figure 4). They restored the section shown 135 in Figure 3, and used this restoration to describe three principal phases of salt-related 136 deformation in the Kwanza Basin. First, an early Albian phase of gravity gliding initiated shortly 137 after salt deposition, as the margin tilted during post-rift thermal subsidence. The rate of gravity 138 gliding slowed in the late Albian due to thinning of the salt beneath the updip extensional domain. 139 Second, a phase of rejuvenated salt tectonics occurred in the Campanian, linked to crustal uplift 140 in the distal basin. During this phase the Angola salt nappe was expelled seaward above the distal 141 ramp and onto newly emplaced oceanic crust. Finally, in the Miocene, the rate of downslope 142 translation increased once more as the basin slope (and base-salt) steepened in response to 
143 continental uplift. Due to these phases of salt-related deformation, the Kwanza Basin is now 144 characterised by a diverse range of salt-related structures associated with complex suprasalt 145 deformation patterns (Duval et al., 1992; Lundin, 1992; Spathopoulos, 1996; Peel et al., 1998; 146 Marton et al., 2000; Jackson et al., 2001; Hudec and Jackson, 2002; Fort et al., 2004; Hudec and 147 Jackson, 2004; Quirk et al., 2012).

148 In terms of the regional structural framework established by Hudec and Jackson (2004), the study 149 area falls within the intermediate domain between pure updip extension and pure downdip 150 contraction (i.e. the relatively undeformed zone of pure translation is lacking cf. Figure 1a) (Figure 151 3). Hudec and Jackson (2004) refer to this area as the 'monocline' and 'diapir' domains. The 152 monocline domain is characterised by subhorizontal or landward-dipping packages of sediments 153 that terminate against prominent onlap surfaces. The diapir domain is characterised by a diverse 154 variety of salt structures including salt-cored anticlines, salt rollers, stocks, walls and 155 allochthonous sheets. The salt structures and associated stratigraphic packages imaged within 156 the study area will be described and interpreted in Sections 4 and 5. 


\section{Data and Methods}

158 We use a 3D seismic cube, acquired by CGG, covering a broadly rectangular area of $2915 \mathrm{~km}^{2}$ 159 offshore Angola (Figure 4). The Pre-Stack Depth Migrated (PSDM) BroadSeis ${ }^{\mathrm{TM}}$ data are excellent 160 quality and image down to the base-salt, which lies up to $5.5 \mathrm{~km}$ below the seabed. The data are 161 zero phase and normal polarity, with a downward increase in acoustic impedance (e.g. top salt) 162 defined by a positive/negative reflection (i.e. blue/red on displayed seismic profiles). The vertical 163 and horizontal resolution are approximated by a quarter of the dominant wavelength of the data, 164 yielding c. $3.5 \mathrm{~m}(\lambda=14 \mathrm{~m})$ at the seabed and c. $30 \mathrm{~m}(\lambda=120 \mathrm{~m})$ at a depth of $5 \mathrm{~km}($ Brown, 2011).

165 We mapped several key horizons across the dataset; these were selected based on their regional 166 significance (i.e. truncation marking an unconformity, or change in seismic character inferred to 167 mark a significant lithological boundary). The mapped surfaces show the present basin geometry. 168 These surfaces are used to calculate isopachs that show the distribution and evolution of 169 sedimentary depocentres through time, and which we primarily relate to salt-driven deformation 170 and related changes in accommodation. A lack of available well data means that lithologies and 171 absolute ages are unconstrained. However, in order to approximate horizontal translation rates, 172 Top Albian, Top Eocene and Top Miocene ages are tentatively assigned based on a correlation 173 with surfaces and units published by Hudec and Jackson (2004). Note, however, that we focus 174 primarily on the relative timing of events based on seismic-stratigraphic analysis, rather than the 175 absolute timing with regards to the regional tectono-stratigraphic framework. 


\section{Basin Structure}

\section{$177 \quad 4.1$ Base-Salt}

178 The base-salt surface (Figure 5a) dips dominantly to the SW with an average dip of $7^{\circ}$, although 179 we observe significant local changes in both dip and dip direction. The most striking feature is 180 the NW-trending, SW-dipping ramp across the eastern, updip edge of the study area (Figure 5a; 181 see also Figure 6). The ramp, presumed to be a degraded relict fault scarp, formed during the 182 earlier rifting phase (Figure 3a; see also Hudec and Jackson, 2004) and has c. $1.3 \mathrm{~km}$ of relief and 183 an average dip of $12^{\circ}$. In detail, despite being broadly perpendicular to the base-salt dip direction, 184 the ramp trend changes along strike. Furthermore, some segments of the ramp, in plan-view, 185 have a convex-, whereas others have a concave-, towards-the-basin geometry. We also note 186 several sub-circular, isolated base-salt highs (Figure 5a).

$187 \quad 4.2$ Salt Thickness

188 The salt isopach map (Figure 5b) shows the distribution of salt structures across the study area. 189 These structures display a wide range of orientations and geometries, with no clear systematic 190 pattern to their spatial distribution. The salt structures, in addition to displaying different trends 191 across the study area, vary in structural style (e.g Figure 6). For example, some are associated 192 with normal faults and salt rollers, whereas others are spatially related to thrust faults and buckle 193 folds. We provide a detailed description of these salt structures, and their relationship to the 194 base-salt geometry and overburden structures in Section 6.

1954.3 Overburden

196 We map four main supra-salt seismic-stratigraphic units (Figure 8a-d; corresponding to units 197 highlighted in Figure 6). The thickness map for Unit 1, which broadly equates to the Albian 198 interval, is the most uniform, showing a gradual increase in thickness to the south-east (from c. 199400 to c. $1200 \mathrm{~m}$ ) (Figure 8a). The unit is absent where it has been subsequently pierced by the 200 underlying salt (e.g. Figure 6), but unlike the overlying units, there are only minor and local, salt201 related thickness changes, on the order of c. $200-300 \mathrm{~m}$ ). 
202 By comparison, the thickness patterns for Units 2-4 (Figure 8b-d) are considerably more complex.

203 Of particular note are the prominent, NNE-to-NNW-trending depocentres visible in all three 204 isopachs, where the unit thickness increases from c. $500 \mathrm{~m}$ to $>1500 \mathrm{~m}$ over a relatively short $(<5$ $205 \mathrm{~km}$ ) length scale. These depocentres contain stacked packages of landward-thickening and 206 dipping strata that onlap or downlap their immediately underlying units (Figure 6). These are the 207 same packages of landward-dipping strata identified by Hudec and Jackson (2004) in their 208 monocline domain (see Section 2). We describe and interpret the origin of these complex 209 overburden thickness patterns below (Section 5). 
211 We interpret that the landward-thickening and -dipping packages described in Section 4.3 (Figure

212 6) form a series of stacked 'ramp-syncline basins' (RSBs) that developed in response to the

213 progressive downdip translation of the salt and its overburden across the major base-salt ramp

214 located along the updip edge of the study area (Figure 5a) (Peel et al., 1998; Marton et al., 1998;

215 Jackson et al., 2001; Jackson and Hudec, 2005; Dooley et al., 2017; Pichel et al., 2018; Dooley et

216 al., 2018; Pichel et al., 2019). A RSB is defined as a "translating growth syncline that gradually

217 moves seaward on a dipping detachment as if on a conveyor belt" by Hudec and Jackson (2017).

218 Translation over the seaward-dipping ramp continually creates accommodation on the downdip

219 side of the ramp, causing syn-kinematic strata to thicken landward into the ramp (Figure 7). As

220 displacement continues, strata are rotated downward such that primary onlap relationships now

221 appear as downlap relationships. The RSBs are therefore recognised by their characteristic

222 pseudo-downlap surface and monoclinal geometry of the growth strata (Jackson and Hudec,

223 2005). Similar examples have previously been described on the Angolan margin using 2D seismic

224 data (Peel et al., 1998; Marton et al., 1998; Jackson et al., 2001; Jackson and Hudec, 2005), and

225 using 3D data from the conjugate margin in the Santos Basin, offshore Brazil (Pichel et al. 2018).

226 RSBs have also been produced in physical analogue models (Dooley et al., 2017; Dooley et al.,

227 2018) and numerical models (Pichel et al., 2018) (Figure 7).

228 We interpret that the RSBs imaged in the dataset are genetically related to the base-salt ramp 229 located immediately updip (Fig. 5a). Given that each RSB forms at the same position above the 230 major base-salt ramp and is subsequently translated seaward as salt flow progresses, we can 231 reconstruct the overburden translation through time by mapping-out the sedimentary 232 depocentres and their onlaps, and laterally restoring them to their initial positions adjacent to 233 the ramp. The lowermost, and thus earliest, onlap onto the base of each RSB is laterally restored 234 to its original position above the updip hinge of the ramp (Figure 6), and the associated 235 depocentres are fitted as closely as possible to their (inferred) original positions directly overlying 236 the ramp (Figure 8e-g), as shown by physical and numerical models (Dooley et al., 2017; Dooley 237 et al., 2018; Pichel et al., 2018). This process is relatively straightforward for the large, elongate 
238 RSB depocentres, hence their original positions are quite well-constrained. However, it is more 239 difficult to restore the original positions of the smaller, more rounded, yet clearly RSB-related 240 depocentres located in the NW of the study area (Figure 8e-g). We therefore focus the discussion 241 here on the N-trending, linear RSBs for which we can make a confident restoration. The 242 approximate original positions of the smaller depocentres use the vectors and displacement 243 magnitudes given by the larger RSBs to guide their restorations.

244 The earliest onlap contained within the RSB defines the net distance of translation (Pichel et al., 245 2018). Our analysis shows that the oldest RSB, RSB 1, records $23.2 \mathrm{~km}$ of seaward translation, 246 and $32^{\circ}$ of clockwise rotation from its original position to its present day position (Figure 8e). 247 Note that this is a minimum estimate of the total horizontal translation, as it does not include 248 any translation that may have occurred during the Albian, prior to the development of the RSB. 249 Our estimate does, however, broadly agree with the estimate of Hudec and Jackson (2004), who 250 calculated at least $20 \mathrm{~km}$ of lateral translation based on their structural restoration. We infer the 251 earliest onlap surface is approximately end Albian in age (see Section 3), which equates to 23.2 $252 \mathrm{~km}$ of lateral translation in 100.5 Ma (i.e. from the end of the Albian to the present). This yields 253 an average translation rate of c. $0.23 \mathrm{~mm} / \mathrm{yr}$, and an average rotation rate of $0.3^{\circ} / \mathrm{Myr}$. Previous 254 translation estimates using RSBs used 2D seismic sections and were therefore unable to 255 determine any syn-translation rotation; we think this is the first time this phenomenon has been 256 quantified from a salt basin. Plan-view rotation of salt structures associated with salt flow over 257 base-salt relief has been suggested from analysis of seismic reflection data in the Santos Basin, 258 offshore Brazil (Pichel et al., 2019), and documented in physical models (Dooley and Hudec, 259 2017).

260 RSB 2 overlies RSB 1 (Figure 6), and is now located c. $11.3 \mathrm{~km}$ seaward from, and has rotated 261 clockwise $12^{\circ}$ from, its causal ramp (Figure 8f), whereas the youngest, RSB 3, is located $5.4 \mathrm{~km}$ 262 seaward of the ramp and has undergone $5^{\circ}$ of clockwise rotation (Figure $8 \mathrm{~g}$ ). If we apply the 263 approximate ages to these units (see Section 3), we can estimate the incremental change in rates 264 of translation and rotation through time (Table 1). 
265 This analysis suggests that translation and rotation rates were approximately constant from the 266 end of the Albian up to the Miocene, at which point they both increased (see Figure 9, in which $26710 \%$ error bars shown for each data point), an observation is consistent with a previous study by 268 Hudec and Jackson (2004). Translation rates are usually highest during the initial stages of salt 269 tectonics, and decrease through time due to salt thinning and overburden thickening (Jackson 270 and Hudec, 2005). However, in the case of the Kwanza Basin, basement uplift during the Miocene 271 steepened the bathymetric gradient and greatly accelerated downslope translation during the 272 latter stages of margin development (Hudec and Jackson, 2004). Due to the relatively poor age 273 constraints within strata filling the RSBs, we cannot resolve shorter periods of acceleration or 274 deceleration that may have occurred. Rather, our values are broad averages of the rates of 275 translation and rotation for each time step.

276 The RSBs show that the dominant direction of translation is westward, oblique to the dominant, 277 broadly south-westerly base-salt dip direction (Figure 5a). Clockwise rotation of the RSBs may be 278 explained by variations in the depositional thickness of underlying salt. Due to reduced basal 279 drag, areas of thick salt (in the south) would flow faster seaward than areas of thin salt (in the 280 north), thereby causing a net-clockwise rotation of the translating overburden (Jackson and 281 Hudec, 2017). Von Nicolai (2011) used backstripping and isostatic balancing to determine the 282 initial distribution of salt deposited during the Aptian, showing early local thickness changes that 283 suggest the original salt isopach thickened to the south in this area (see her Figure 4.11).

284 Having used the RSBs to interpret and quantify the net overburden translation and rotation 285 associated with salt flow in the region of interest, we now proceed with a seismic-stratigraphic 286 analysis of the individual salt structures. Given that we now know how these structures have 287 moved through time from their original positions on the margin, we can interpret their evolution 288 in the context of this basinward translation and their interaction with base-salt relief.

289 While we are confident applying these translation and rotation estimates to the evolution of local 290 salt structures, we would caution against applying these more widely. A series of thick-skinned 291 transfer faults, which run perpendicular to the margin and segment the Kwanza Basin, are said 292 to allow different amounts of translation on either side of the faults (Duval et al., 1992; 
293 Spathopoulos, 1996). This could mean that the rates of translation and rotation calculated here 294 may only apply locally and may differ along the margin. 
2956 Local Salt Structure Evolution in the Context of Regional Salt Flow

296 The salt structures can be grouped into three broad sets defined by their orientations (Figure 5c):

297 (i) Set 1 - Parallel to margin (NW-SE); (ii) Set 2 - Perpendicular to margin (NE-SW); and (iii) Set 3 298 Oblique to margin (N-S). Each of these sets is also associated with distinctly different structural 299 styles (e.g. salt rollers and turtle structures vs. thrusts and buckle folds). In a classic gravity gliding300 dominated view of salt-influenced passive margins, we might expect elongate salt-related 301 structures (i.e. faults, folds and walls) to be oriented subparallel to the margin (Bally, 1981). As 302 we demonstrate below, the trend and styles of salt structures in this part of the Kwanza Basin 303 deviate from this view, suggesting other processes, such as salt flow over base-salt relief, 304 controlled the structural development of the salt and its overburden. In the following section we 305 describe and interpret the characteristic structural styles of each of the sets, and explore how 306 the base-salt relief may have influenced their structural development during seaward translation.

\subsection{Set 1: Margin-Parallel Salt Structures}

308 6.1.1 Geometry and seismic-stratigraphy

309 There are two NW-trending, margin-parallel salt walls, oriented perpendicular to the general 310 base-salt dip direction and oblique to the dominant (westerly) gliding direction (Figure 5c). The 311 major base-salt ramp is located c. $15 \mathrm{~km}$ updip of, and is subparallel to, these two walls. Both salt 312 walls have a broadly triangular shape in cross section, defined by a wide base and narrow crest, 313 and share similar structural characteristics, but the more northerly structure is significantly larger 314 (Figure 10a). Furthermore, the structural characteristics of the larger wall (Figure 10a) vary along 315 strike. Near the centre, the wall has rounded crests, and is flanked by more steeply dipping strata 316 that only onlap the wall in their upper part (Figure 11a). In contrast, at its end, the wall has lower 317 relief and an irregular crestal geometry defined by 'horn-like' projections of salt (Figure 11b). In 318 this location, two large, inward-dipping, salt-detached normal faults bound a supra-wall graben.

319 Unit 1 is broadly tabular, terminating against the salt wall on both flanks (Figure 10a). However, 320 strata at the base of Unit 1 are folded, with growth strata preserved within synclines (Figure 10b). 321 The folds and related growth strata are draped by more tabular, largely deformed strata. Unit 2, 
322 however, thins onto both flanks of the salt wall, and forms part of the fill of RSB 1 on the updip

323 side of the structure (Figure 10a). Unit 3 marks a significant change in structural style as it thickens

324 across a series of inward-dipping, graben-defining normal faults developed above the salt wall

325 (Figure 10a). Updip, Unit 3 thickens into a salt-detached normal fault located above the major

326 base-salt ramp. Unit 4 is also faulted over the crest of the salt wall, but overall thickens updip

327 into RSB 3.

\subsubsection{Structural Evolution}

329 Based on the geometry and seismic-stratigraphy of the overburden, the structural evolution of 330 the Set 1 salt walls, and their relation to the updip RSB, is summarised here and illustrated 331 schematically in Figure 12.

332 The presence of growth strata shows that the buckle folds formed during deposition of Unit 1, 333 implying salt-related deformation initiated when the overburden was very thin (only c. $0.1 \mathrm{~km}$ 334 thick, based on the thickness of the tabular strata underlying the growth strata; Figure 10b). Our 335 earlier analysis of the RSBs showed that a significant amount (at least c. $23 \mathrm{~km}$ ) of basinward 336 translation has occurred in the area. We therefore propose that this very early contractional 337 deformation may reflect overburden shortening at the base of the ramp as salt flowed seaward 338 (Figure 2d) (e.g. Dooley et al., 2017; 2018). As a result, the thin overburden buckled to form low339 amplitude, small-wavelength folds at the base of the ramp (Figure 12a; Figure 17a). The buckle 340 folds were subsequently translated further downdip to their present position. These kinematics 341 and related structural style are analogous to the translated fold-belt of prekinematic strata 342 generated in a physical model by Dooley et al. (2017) (see their Figure 25).

343 Thinning of Unit 2 onto the large salt wall indicates that it had a topographic expression on the 344 seafloor during deposition. The associated buckle folds suggest a possible contractional origin for 345 the diapiric structure, which may have initially formed as a salt-cored anticline (Figure 12b; Figure 346 17b). An alternative interpretation is that the structure formed at the extensional hinge at the 347 top of the ramp (Figure $2 \mathrm{~d}$ ), but we favor the contractional origin because buckle folds of similar 348 age occur on the updip flank of the structure. Once the initial anticline had formed, subsidence 
of strata immediately flanking the walls occurred as salt was drawn into the core of the growing structure. Sediment loading would have then amplified this effect and driven continued growth of the structure as it translated basinward.

352 Following continued sediment deposition, the overburden reached a critical thickness where it 353 became too strong to buckle at the base of the ramp. The buckle folds and salt-cored anticlines 354 were thus passively translated downdip as gliding continued, and a RSB formed above the ramp 355 due to an imbalance in salt flux (Figure 12c). The RSB is essentially the expression of the hinge pair/monocline as the roof thickens and strengthens.

357 A phase of extension, possibly related to salt acceleration as the margin steepened and base-salt 358 dip increased, then caused two graben to develop. One graben developed over the crest of the 359 salt-cored anticline where the overburden was thin and therefore mechanically weak, whereas 360 the other formed over the extensional hinge of the ramp where the stress is greatest (Figure 361 12d). Overburden extension initiated reactive diapiric rise and allowed the salt to penetrate to 362 the seafloor (Vendeville and Jackson, 1992a) (Figure 17c).

363 As the diapir rose reactively and drew in more salt, the seaward-dipping, graben-bounding fault 364 above the ramp became dominant, growing and detaching into the salt (Figure 12e). Normal 365 displacement on the fault facilitated the downslope transport of material in this location (Figure 366 12f), laterally equivalent to RSB 2 developing along strike to the SE. Eventually, diapir growth 367 slowed and it became buried, as the source layer thinned and almost welded (Figure 12g).

368 Following reactive rise, the salt wall was tall enough, and the overburden thin enough, to permit 369 active rise by buoyancy in the centre of the salt wall. The diapir assumed a more rounded 370 geometry characteristic of active rise in this location (Jackson and Hudec, 2017) (Figure 11a; 371 Figure 17d). In order to feed the actively rising central diapir, salt flowed along-strike from its 372 ends, causing the ends of the salt wall to collapse/fall (Vendeville and Jackson, 1992b) (Figure 373 11b). The diapir welded on its north-eastern margin, and only a thin connection to the adjacent 374 salt pillow on the south-western edge remains (Figure 10a), thus salt flowed more easily within 375 the salt wall itself. Onlapping strata in the youngest package indicate active rise may be ongoing, 
376 although the lack of topographic expression on the present seafloor suggests that either the

377 sediment accumulation rate keeps pace with the rate of diapir rise, or that the active rise has 378 very recently ceased (Figure 17e).

\subsection{Set 2: Margin-Perpendicular Salt Structures}

\subsubsection{Geometry and Seismic Stratigraphy}

381 The NE-trending salt walls are oriented perpendicular to the margin and parallel to the general 382 base-salt dip (Figure 5c). These walls have strikingly different structural characteristics to Set 1 383 (Figure 13). For example, in contrast to walls defining Set 1, which are broad and normal faulted 384 across the crest, walls in Set 2 are short and narrow, each being associated with a thrust fault 385 that detaches in the crest of the structure (Figure 13a). The predominantly SE-dipping thrust 386 faults are confined to Units 1 and 2, terminating at the contact between Units 2 and 3.

387 Unit 1 comprises a series of discrete rafts, within which strata thicken to the south-east (Figure 388 13a). Unit 2 overlies Unit 1 conformably and fills depocentres between detached blocks of Unit 389 1. Locally, Unit 2 strata define antiformal 'turtle' structures filled with growth strata (Figure 13b). 390 Unit 3 drapes the salt walls and intervening depocentres unconformably, and overlying units are 391 undeformed. Strata at the base of Unit 4 appear to downlap Unit 3; this relationship arises 392 because Figure 13a represents an oblique, NW-trending section through a broadly N-trending 393 RSB. Of particular note in Unit 3 is the broad anticline directly above a topographic high on the 394 base-salt surface; we return to the significance of this structure below.

\subsubsection{Structural Evolution}

396 The schematic structural evolution of the Set 2 salt walls is shown in Figure 14. We propose that 397 these salt walls initiated in response to a phase of early extension, which was accommodated by 398 formation of predominantly W-dipping normal faults and associated salt rollers (that later 399 evolved into walls; Figure 14a; Figure 17a). Continued extension eventually dissected Unit 1 into 400 a series of detached rafts, with Unit 2 filling the accommodation between the rafts as the salt 401 thinned (Figure 14b; Figure 17b). An extensional turtle structure formed out-of-plane to the NE 
402 (Figure 13b), similar to asymmetric turtle structures previously been identified in the Kwanza 403 Basin (Duval et al., 1992).

404 Using the translation and rotation increments given by the RSBs (Section 5), we can restore the 405 original position of the structures. This shows that the Set 2 structures initially formed outside of 406 the area imaged in our seismic data (Fig. 17a). It is therefore difficult to suggest a mechanism for 407 the extension that triggered salt roller formation. However, based on the magnitude of rotation 408 recoded in the RSBs, we can infer that Set 2 structures originally trended broadly N (Fig. 17a), 409 before being rotated into their present NE trend (Fig. 17e). Furthermore, the dominant (restored; 410 see Fig. 17a) westward dip direction of the normal faults bounding the rollers and rafts suggests 411 formation in response to bulk westward sliding. We therefore tentatively infer that the base-salt 412 dips locally to the west (rather than south-westwards) where the Set 2 structures originated. This 413 would be in line with the regional gliding direction indicated by the RSBs, and consistent with 414 observations of roller and raft development elsewhere (e.g. Duval et al., 1992).

415 The contact between Units 2 and 3 defines the onset of contraction; this exploited the pre416 existing planes of weakness created by the salt rollers, which were relatively weaker than the 417 flanking rafts (Figure 14c; Figure 17c). Note that the thrust faults dip to the SE and cross-cut the 418 oppositely dipping, salt-detached, raft-bounding normal faults, likely because the latter were too 419 steep to be reactivated in a reverse sense. The thrust faults uplifted strata above the salt rollers, 420 which were then locally eroded prior to deposition of Unit 3.

421 The bulk (i.e. regional) shortening direction responsible for squeezing and inversion the Set 2 422 structures is difficult to determine given contraction exploited pre-existing, weak salt rollers; i.e. 423 the maximum principal stress may have been oblique, rather than perpendicular, to the 424 orientation of the salt walls (Duffy et al., 2018). At the onset of shortening the structures would 425 have been approaching a concave-into-the-basin ramp segment (Figure 17c). Local contraction 426 at this time may therefore relate to the onset of convergent radial gliding associated with 427 translation over this concave-into-the-basin ramp (Cobbold and Szatmari, 1991; Tadeu dos Reis 428 et al, 2008). 
429 From the deposition of Unit 3 onward, there is little evidence of salt-related deformation, with 430 Unit 3 draping and burying the established salt walls (Figure 14d; Figure 17d). The broad fold

431 defined at the top of Unit 3, and associated thinning of Unit 4 above the base-salt high, formed 432 as the overburden was folded during overall basinward translation across base-salt relief (Figure 433 14f).

\section{$434 \quad 6.3$ Set 3: Oblique Salt Structures}

\section{$435 \quad$ 6.3.1 Geometry and Seismic Stratigraphy}

436 The $\mathrm{N}$-trending salt structures are (presently) oriented oblique to the general base-salt dip 437 direction, perpendicular to the dominant (westerly) gliding direction (see Section 5), and parallel 438 to the RSBs. Unlike those in sets 1 and 2, most of the structures in Set 3 are high-amplitude salt439 cored anticlines that do not pierce the overlying stratigraphy (i.e. they are not diapirs; Hudec and 440 Jackson, 2011) (Figure 15). There is one exception that has pierced the overburden and 441 penetrates close to the present day sea floor (furthest west in Figure 15). Unit 1 is largely 442 isopachous across the salt-cored anticlines, whereas Unit 2 thins over the crests and thickens 443 dramatically into flanking synclines (Figure 15). Unit 3 onlaps the salt-cored topographic highs, 444 whereas Unit 4 does not markedly changed in thickness across the underlying salt structures.

\section{$445 \quad 6.3 .2$ Structural Evolution}

446 The stratigraphic occurrence of growth strata indicates that Set 3 salt structures had a rapid and 447 short-lived phase of growth during deposition of Unit 2. This is in contrast to Sets 1 and 2, which 448 formed early during deposition of Unit 1 . Set 3 salt structures also differ from Sets 1 and 2 in that 449 they do not show diagnostic characteristics associated with either compression or extension. For 450 example, salt-cored anticlines in Set 3 may have formed as - 1) halokinetic folds, in response to 451 sedimentary loading in the absence of lateral tectonic forces, or 2) contractional folds, in 452 response to lateral compressive forces. Halokinetic folds typically form gradually and are 453 associated with low-relief salt pillows or anticlines, whereas the short-wavelength and tight 454 geometry of these folds, in addition to their relatively rapid growth, is perhaps most consistent 455 with a compressive origin (Jackson and Hudec, 2017). 
456 The schematic structural evolution of the Set 3 salt structures is shown in Figure 16 . The N457 trending salt-cored anticlines are parallel to the $\mathrm{N}$-trending axes of the RSBs and the $\mathrm{N}$-trending 458 segment of the base-salt ramp responsible for their development (Figure 5a). It therefore follows 459 that the compression that generated the folds and salt pillows was also associated with a 460 deceleration during translation across the base-salt ramp. Decelerating flow at the base of the $\mathrm{N}$ 461 trending ramp could have generated the compressive stress in the same way described for the 462 early buckle folds in Section 6.1, but since the amplitude and wavelength of the folds is 463 proportional to the overburden thickness, the folds generated in this case were larger (see Price 464 and Cosgrove, 1990). Downdip welding during this time may also have served to enhance the 465 deceleration and salt accumulation, though the timing of welding is difficult to constrain from 466 the available data. Subsequent downbuilding and sediment loading then drove rapid growth of 467 the anticlines, and in one case the differential loading was sufficient to actively pierce the roof 468 (furthest west in Figure 15). 
470 As described in Section 6, the geometry, position and orientation of the three main RSBs indicate

471 c. $23.2 \mathrm{~km}$ of seaward translation, and up to $32^{\circ}$ of rotation; this indicates that related salt

472 structures are now situated a significant distance from where they originated. Figure 17 shows

473 the active salt-related deformation at each time step, as discussed below.

$474 \quad 7.1$ Albian

475 The broadly isopachous nature of the Albian indicates: (i) the seabed was broadly flat during its 476 deposition, and thus that the salt had infilled relict, rift-related topography, and broadly 477 thickened seaward; and (ii) regional gravity gliding commenced post-Albian (i.e. the RSBs are 478 strictly post-Albian). However, Albian growth strata indicate that local thin-skinned deformation 479 did occur in at least two areas at this time: (i) at the base of the ramp, in an area of salt and 480 overburden contraction; and (ii) updip, outside of the area of data coverage, where we suggest 481 that early extension drove formation of the somewhat enigmatic, slope-parallel, Set 2 salt rollers 482 (Figure 17a).

\section{$483 \quad 7.2$ Upper Cretaceous to Eocene}

484 Regional gliding had fully initiated by the end of the Albian, by which time the overburden had 485 thickened and strengthened. This resulted in the development of the first RSB as the salt and 486 overburden were translated over the base-salt ramp (Figure 17b). As the thick salt continued to 487 flow seaward, away from the ramp, accommodation was created adjacent to the ramp, 488 producing landward-thickening and dipping growth packages that onlapped underlying Albian 489 strata. The onset of regional gliding can be attributed to regional tilting of the base-salt driven by 490 thermal subsidence to the SW within the deep basin (Brice et al., 1982; Hudec and Jackson, 2004). 491 The angle necessary to create basin-scale gravitational instability and to thus induce regional 492 gliding can be as little as $1-2^{\circ}$ (Peel, 2014).

493 We suggest the salt-cored anticlines formed at this time at the base of the ramp as the mismatch 494 in salt flux causes deceleration and contraction of the thickening overburden (Dooley et al., 495 2017). Syn-kinematic sediments accumulated within synclinal depocentres, driving further 
496 growth of the anticlines. Updip of the growing salt-cored anticlines, extension continues to

497 dominate the development of the Set 2 structures, creating rafts and turtle structures. Albian 498 rafting has previously been documented elsewhere in the Kwanza Basin (Burollet, 1975; Duval et 499 al., 1992; Lundin, 1992; Mauduit et al., 1997). In these studies the orientation of the early formed 500 rafts was inferred to be parallel to the margin, although they were imaged on 2D seismic lines 501 (i.e. the true relationship between base-salt dip, margin trend, and raft trend was unknown).

\section{7.2.1 Oligocene to Miocene}

503 The Set 1 salt structures are translated away from the base of the ramp and enter an extensional 504 stress field, which transforms the salt-cored anticline into a reactive diapir (Figure 17c). This 505 extension may relate to local acceleration resulting from translation over a steeper part of the 506 base-salt surface, which served to locally increase the rate of seaward salt flow. We argue that 507 local rather than regional stresses drove this change in deformation style, given that the adjacent 508 Set 2 structures enter a phase of contraction at this time.

509 Whilst structures within Sets 1 and 2 continued to grow during this period due to squeezing and 510 reactive rise, those within Set 3 became inactive and were eventually buried.

\section{7.2.2 Miocene to Recent}

512 The RSBs record an increase in translation rate at this time (from c. 0.2 to $1 \mathrm{~mm} / \mathrm{yr}$ ), despite 513 thinning of the salt (Figure 9). This is attributed to margin uplift during the Miocene, which 514 thereby increased gravitational instability (Lunde et al., 1992; Lundin, 1992; Hudec and Jackson, 515 2004). Thinning and onlapping of strata across major salt structures indicate that some were tall 516 enough (relative to their overburden thickness) to actively rise and arch their overburden (Figure 517 17d). Other structures were passively translated and buried as the salt source layer was too thin 518 to feed them. Welds develop and translation rates consequently slowed.

\section{$519 \quad 7.2 .3 \quad$ Present}

520 The salt thickness map shows that, at present, most of the study area adjacent to the well521 developed salt walls is very close to welding (Figure 5b). This means that there is increased basal 
522 drag on the salt, and that seaward translation of salt and overburden is correspondingly slow.

523 The youngest strata still thicken into the youngest RSB, but rather than onlapping its seaward-

524 dipping flank, they thin up onto the ramp, indicating basinward translation persists at a slow rate.

525 This is further supported by the fact that the seabed shows no expression of the RSB, indicating

526 that aggradation keeps up with the rate of displacement. Two salt structures continue to actively

527 rise and thus deform the seabed, but the majority of salt structures are inactive and are being 528 buried (Figure 17e). 


\section{Discussion}

530 Classic models of salt-influenced passive margins cannot explain the diversity of structural styles

531 and orientations of the salt structures observed in the Outer Kwanza Basin, offshore Angola. Each

532 salt structure set is associated with a unique structural evolution, with many showing evidence

533 for multiple phases of reactivation and inversion. Another key observation is that phases of

534 extension and contraction were synchronous in closely spaced salt structures. This means we 535 cannot appeal to basement-involved shortening as in the Inner Kwanza Basin (Hudec and Jackson, 536 2002). We suggest this complexity reflects the interaction of seaward salt flow with considerable 537 base-salt topography. A key consequence of this process is that the mid-slope zone of translation, 538 which in classic models is shown to be largely undeformed (Fig. 1a; see Jackson et al., 1994; 539 Schultz-Ela, 2001; Fort et al. 2004; Hudec and Jackson, 2004; Brun and Fort, 2011; Peel, 2014), 540 may in fact be an area of very complex deformation.

541 Salt deformation on the Angolan margin initiated early in response to gravity gliding but the 542 interaction of salt flow with base-salt topography controlled the subsequent structural evolution, 543 and produced a much more complicated set of salt structures than would typically be associated 544 with salt-influenced passive margins (i.e. margin-parallel structures defining extensional, 545 translational and compressional domains).

546 Physical models by Dooley et al. (2017) and Dooley et al. (2018) show that the basinward flow of 547 salt and overburden across base-salt relief can generate local extension and contraction 548 anywhere along a margin. Because of this, pre-existing, diapiric and non-diapiric structures can 549 be inverted multiple times as they migrate through these various stress fields. These local stress 550 fields explain how structures from the Kwanza Basin comprise extensional diapirs which are 551 subsequently squeezed during contraction, and folds which evolved into reactive diapirs due to 552 late extension. These structures are very similar to those developed in the multi-ramp models by 553 Dooley et al. (2018), with even greater complexities seen in models with isolated ramps (see their 554 model 5; Fig. 16. These local stress fields also explain how structures experience very different 555 tectonic evolutions, depending on their starting position on the margin and path taken during 556 downdip translation. Consequently, salt structures in the Kwanza Basin have complex 
557 evolutionary histories comprising phases of both extension and compression, and different salt 558 structures are associated with different evolutionary histories as they respond to local stresses 559 caused by the underlying topography over which they are translated.

560 In the Kwanza Basin, steep, seaward-dipping ramps, which change orientation along strike, had 561 the greatest impact on salt-related deformation. Changes in the flux of salt over these ramps 562 generate local stresses that deform the salt and its overburden. Convex- and concave-into-the563 basin segments of the ramps may have also initiated locally divergent and convergent gliding 564 (Cobbold and Szatmari, 1991; Tadeu dos Reis et al., 2008). The effect of these local stresses on 565 overburden deformation depends on the thickness of the latter, and the presence and orientation of any pre-existing weaknesses (e.g. precursor diapirs).

567 Unlike the strike-elongate, broadly linear base-salt ramps, the more isolated, sub-circular base568 salt highs are not obviously associated with any salt structures or specific style of overburden 569 deformation. The reason for this is not yet clear, although this observation may suggest there is 570 a critical ratio between salt thickness and relief height; i.e. a threshold value must be reached 571 before stresses induced at the base of the salt are transferred into the overburden. Or put 572 another way, low-relief features only produce stress perturbations sufficient to deform the 573 overburden when the salt is very thin. An alternative interpretation for the apparent lack of 574 structures above isolated base-salt highs is that any structures that did form have since been 575 translated out of the study area or overprinted by later deformation. Other controls on the 576 structural evolution of the salt and overburden which require further study include: 577 sedimentation rate and distribution, the composition and rheology of both the salt (i.e. in case 578 where the salt is mechanically layered; e.g. Van Gent et al., 2010; Fiduk and Rowan, 2012; Jackson 579 et al., 2014, 2015) and overburden, and the role of active basement-involved tectonics.

580 This study concludes that, in this area downdip translation over base-salt topography played a 581 key role in the structural evolution of the salt walls. The diversity of salt wall orientations and 582 structural styles in the Kwanza Basin demonstrates the significant impact which salt flow over 583 base-salt topography can have on the structural evolution of the basin. We suggest that the 584 effects of base-salt relief in the Kwanza Basin are important because the ratio of base-salt relief 
585 to depositional salt thickness is high. Only when this ratio is low (e.g. for a smooth base-salt

586 surface) may simple models of gravity gliding and spreading accurately capture the origin and 587 evolution of salt structures on a margin. 


\section{Conclusions}

589 We used 3D seismic data to reconstruct the tectono-stratigraphic evolution of the Outer Kwanza 590 Basin, with the aim being to investigate how the interaction of salt flow with base-salt relief 591 influenced the origin and growth of salt structures on the margin. The key conclusions of our 592 study are:

593

- Ramp-syncline basins record a minimum of $23 \mathrm{~km}$ of translation and 32 degrees of 595 rotation in the mid-slope domain of the Outer Kwanza Basin

- Clockwise direction of rotation suggests increasing velocities, and therefore increasing salt thickness, to the south

- Salt tectonics in the Kwanza Basin is characterised by advanced diapiric salt structures. The salt structures can be divided broadly into three sets characterised by their orientations and structural styles.

- The stratigraphic relationships in the overburden indicate that the evolutionary history of each set is unique and cannot be explained in terms of conventional models of gravity gliding and gravity spreading on salt-influenced passive margins.

- The effects of salt flow over base-salt relief played a crucial role in the development of the salt structures. The local variations in salt flux cause local compression or extension, thereby fundamentally controlling the spatial distribution, orientation and structural style of the salt structures. 
609 Bally, A.W., 1981. Thoughts on the tectonics of folded belts. Geological Society, London, Special 610 Publications, 9(1), pp.13-32.

611 Brice, S.E., Cochran, M.D., Pardo, G. and Edwards, A.D., 1982. Tectonics and Sedimentation of the 612 South Atlantic Rift Sequence: Cabinda, Angola: Rifted Margins: Field Investigations of Margin 613 Structure and Stratigraphy.

614 Brink, A.H., 1974. Petroleum geology of Gabon basin. AAPG Bulletin, 58(2), pp.216-235.

615 Brown, A.R., 2011. Interpretation of three-dimensional seismic data. Society of Exploration 616 Geophysicists and American Association of Petroleum Geologists.

617 Brun, J.P. and Fort, X., 2011. Salt tectonics at passive margins: Geology versus models. Marine 618 and Petroleum Geology, 28(6), pp.1123-1145.

619 Burollet, P.F., 1975. Tectonique en radeaux en Angola. Bulletin de la Société géologique de 620 France, 7(4), pp.503-504.

621 Cobbold, P.R. and Szatmari, P., 1991. Radial gravitational gliding on passive margins. 622 Tectonophysics, 188(3-4), pp.249-289.

623 Dooley, T.P. and Hudec, M.R., 2017. The effects of base-salt relief on salt flow and suprasalt 624 deformation patterns-Part 2: Application to the eastern Gulf of Mexico. Interpretation, 5(1), 625 pp.SD25-SD38.

626 Dooley, T.P., Hudec, M.R., Carruthers, D., Jackson, M.P. and Luo, G., 2017. The effects of base627 salt relief on salt flow and suprasalt deformation patterns-Part 1: Flow across simple steps in 628 the base of salt. Interpretation, 5(1), pp.SD1-SD23.

629 Dooley, T.P., Hudec, M.R., Pichel, L.M. and Jackson, M.P., 2018. The impact of base-salt relief on 630 salt flow and suprasalt deformation patterns at the autochthonous, paraautochthonous and 631 allochthonous level: insights from physical models. Geological Society, London, Special 632 Publications, 476, pp.SP476-13.

633 Duffy, O.B., Dooley, T.P., Hudec, M.R., Jackson, M.P., Fernandez, N., Jackson, C.A. and Soto, J.I., 634 2018. Structural evolution of salt-influenced fold-and-thrust belts: a synthesis and new insights 635 from basins containing isolated salt diapirs. Journal of Structural Geology, 114, pp.206-221.

636 Duval, B., Cramez, C. and Jackson, M.P.A., 1992. Raft tectonics in the Kwanza basin, Angola. 637 Marine and Petroleum Geology, 9(4), pp.389-404.

638 Evans, R., 1978. Origin and significance of evaporites in basins around Atlantic margin. AAPG 639 Bulletin, 62(2), pp.223-234. 
640 Fort, X., Brun, J.P. and Chauvel, F., 2004. Contraction induced by block rotation above salt 641 (Angolan margin). Marine and Petroleum Geology, 21(10), pp.1281-1294.

642 Gaullier, V., Brun, J.P., Gue, G. and Lecanu, H., 1993. Raft tectonics: the effects of residual 643 topography below a salt decollement. Tectonophysics, 228(3-4), pp.363-381.

644 Hudec, M.R. and Jackson, M.P., 2002. Structural segmentation, inversion, and salt tectonics on a 645 passive margin: Evolution of the Inner Kwanza Basin, Angola. Geological Society of America 646 Bulletin, 114(10), pp.1222-1244.

647 Hudec, M.R. and Jackson, M.P., 2004. Regional restoration across the Kwanza Basin, Angola: Salt 648 tectonics triggered by repeated uplift of a metastable passive margin. AAPG bulletin, 88(7), 649 pp.971-990.

650 Hudec, M.R., Norton, I.O., Jackson, M.P. and Peel, F.J., 2013. Jurassic evolution of the Gulf of 651 Mexico salt basin. AAPG bulletin, 97(10), pp.1683-1710.

652 Jackson, M.P. and Hudec, M.R., 2005. Stratigraphic record of translation down ramps in a passive653 margin salt detachment. Journal of Structural Geology, 27(5), pp.889-911.

654 Jackson, M.P. and Hudec, M.R., 2017. Salt tectonics: Principles and practice. Cambridge 655 University Press.

656 Jackson, M.P., Hudec, M.R., Fraenkl, R., Sikkema, W., Binga, L. and Da Silva, J., 2001. Minibasins 657 translating down a basement ramp in the deepwater monocline province of the Kwanza Basin, 658 Angola [abs.]. In American Association of Petroleum Geologists Annual Meeting Official Program 659 (Vol. 10, p. A99).

660 Jackson, M.P., Vendeville, B.C. and Schultz-Ela, D.D., 1994. Structural dynamics of salt systems. 661 Annual Review of Earth and Planetary Sciences, 22(1), pp.93-117.

662 Lunde, G., Aubert, K., Lauritzen, O. and Lorange, E., 1992. Tertiary uplift of the Kwanza Basin in 663 Angola. Géologie Africaine: Coll. Géol. Libreville, Recueil des Communications. Elf Aquitaine, 664 Boussens, France, pp.99-117.

665 Lundin, E.R., 1992. Thin-skinned extensional tectonics on a salt detachment, northern Kwanza 666 Basin, Angola. Marine and Petroleum Geology, 9(4), pp.405-411.

667 Marton, L.G., Tari, G.C. and Lehmann, C.T., 2000. Evolution of the Angolan passive margin, West 668 Africa, with emphasis on post-salt structural styles. Geophysical Monograph-American 669 Geophysical Union, 115, pp.129-150.

670 Mauduit, T., Guerin, G., Brun, J.P. and Lecanu, H., 1997. Raft tectonics: the effects of basal slope 671 angle and sedimentation rate on progressive extension. Journal of Structural Geology, 19(9), 672 pp.1219-1230. 
673 Peel, F.J., 2014. The engines of gravity-driven movement on passive margins: Quantifying the 674 relative contribution of spreading vs. gravity sliding mechanisms. Tectonophysics, 633, pp.126675142.

676 Peel, F., Jackson, M. and Ormerod, D., 1998. Influence of major steps in the base of salt on the 677 structural style of overlying thin-skinned structures in deep water Angola. In American 678 Association of Petroleum Geologists International Conference and Exhibition, Rio de Janeiro, 679 Brazil, November, Extended Abstracts Volume (pp. 366-367).

680 Pichel, L.M., Peel, F., Jackson, C.A. and Huuse, M., 2018. Geometry and kinematics of salt681 detached ramp syncline basins. Journal of Structural Geology, 115, pp.208-230.

682 Pichel, L.M., Jackson, C.A.L., Peel, F. and Dooley, T.P., 2019. Base-Salt Relief Controls on Salt683 Tectonic Structural Style, São Paulo Plateau, Santos Basin, Brazil. Basin Research.

684 Price, N.J. and Cosgrove, J.W., 1990. Analysis of geological structures. Cambridge University 685 Press.

686 Quirk, D.G., Schødt, N., Lassen, B., Ings, S.J., Hsu, D., Hirsch, K.K. and Von Nicolai, C., 2012. Salt 687 tectonics on passive margins: examples from Santos, Campos and Kwanza basins. Geological 688 Society, London, Special Publications, 363(1), pp.207-244.

689 Rowan, M.G., Peel, F.J., Vendeville, B.C. and Gaullier, V., 2012. Salt tectonics at passive margins: 690 Geology versus models-Discussion. Marine and Petroleum Geology, 37(1), pp.184-194.

691 Schultz-Ela, D.D., 2001. Excursus on gravity gliding and gravity spreading. Journal of Structural 692 Geology, 23(5), pp.725-731.

693 Spathopoulos, F., 1996. An insight on salt tectonics in the Angola Basin, South Atlantic. Geological 694 Society, London, Special Publications, 100(1), pp.153-174.

695 Tadeu dos Reis, A., Gorini, C., Weibull, W., Perovano, R., Mepen, M. and Ferreira, É., 2008. Radial 696 gravitational gliding indicated by subsalt relief and salt-related structures: the example of the 697 Gulf of Lions, western Mediterranean. Revista Brasileira de Geofísica, 26(3), pp.347-365.

698 Vendeville, B.C. and Jackson, M.P., 1992a. The rise of diapirs during thin-skinned extension. 699 Marine and Petroleum Geology, 9(4), pp.331-354.

700 Vendeville, B.C. and Jackson, M.P.A., 1992b. The fall of diapirs during thin-skinned extension. 701 Marine and Petroleum Geology, 9(4), pp.354-371.

702 von Nicolai, C., 2011. The Interplay of Salt Movements and Regional Tectonics at the Passive 703 Continental Margin of the South Atlantic, Kwanza Basin. Unpublished PhD thesis. Universität 704 Potsdam. [https://goo.gl/8LwQBY] 
705 Weijermars, R., Jackson, M.T. and Vendeville, B., 1993. Rheological and tectonic modeling of salt 706 provinces. Tectonophysics, 217(1-2), pp.143-174. 
$707 \quad 11$ Tables

\begin{tabular}{|c|c|c|c|c|c|}
\hline & $\begin{array}{l}\text { Time } \\
\text { (Ma) }\end{array}$ & $\begin{array}{l}\text { Displacement } \\
(\mathbf{k m})\end{array}$ & $\begin{array}{l}\text { Rotation } \\
\text { (deg) }\end{array}$ & $\begin{array}{l}\text { Translation } \\
\text { rate }(\mathrm{mm} / \mathrm{yr})\end{array}$ & $\begin{array}{l}\text { Rotation rate } \\
\text { (deg/Myr) }\end{array}$ \\
\hline & 100.5 & 0 & 0 & & \\
\hline RSB 1 & 33.9 & 11.9 & 20 & 0.18 & 0.30 \\
\hline RSB 2 & 5.3 & 17.8 & 27 & 0.21 & 0.24 \\
\hline RSB 3 & 0 & 23.2 & 32 & 1.0 & 0.90 \\
\hline
\end{tabular}

708 Table 1: Translation and rotation of ramp syncline basins 

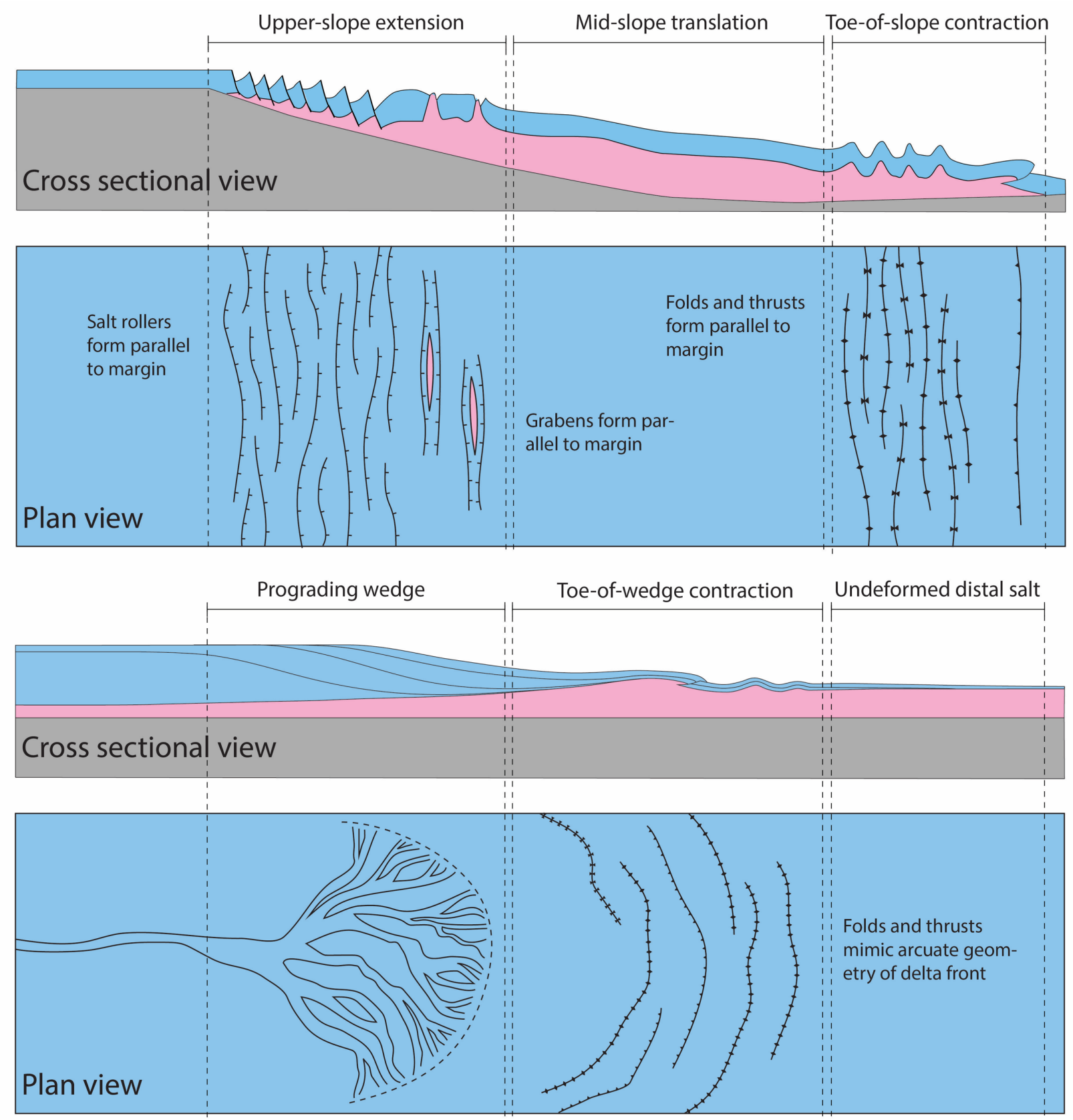

710 Figure 1: Cross sectional and plan view schematic diagrams of end member models of salt 711 tectonic systems: a) gravity gliding, and b) gravity spreading, showing the types of structures 712 and orientations associated with each kinematic domain. 
a)

Thick salt above high block - effect of basal drag minimal

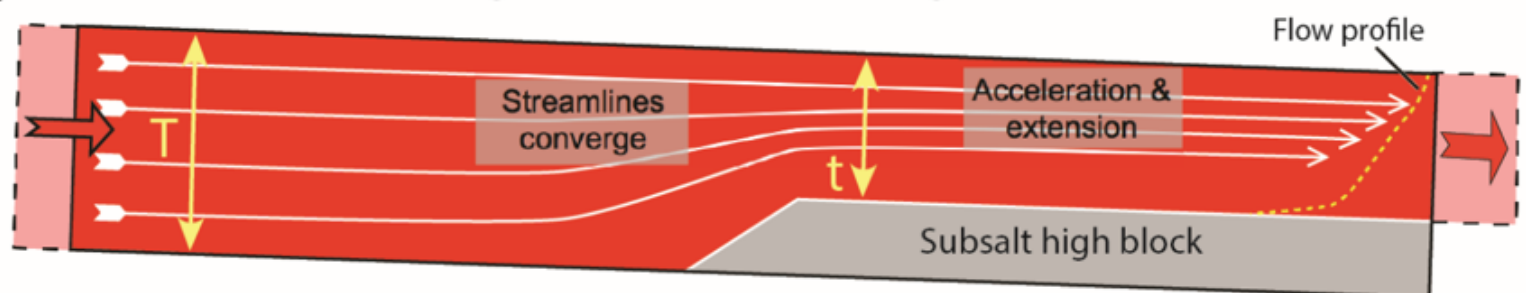

b) High Thin salt above high block - acceleration retarded due to basal drag

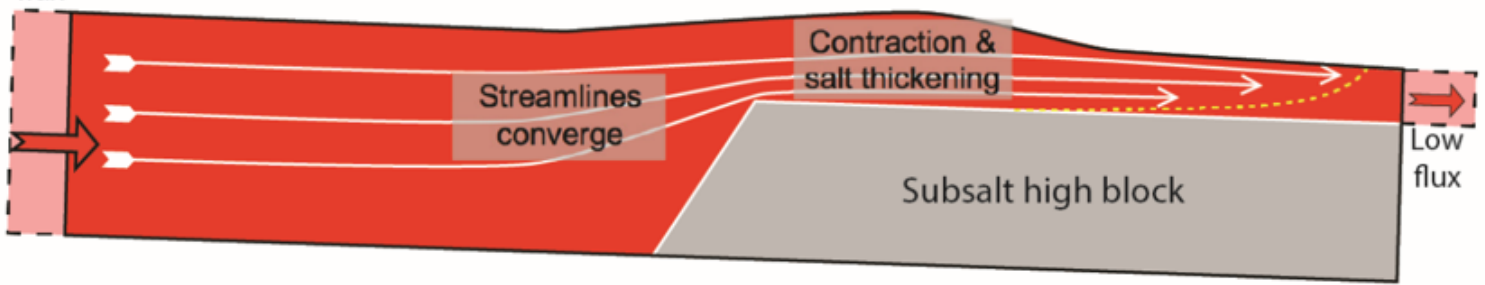

C)

Salt on updip high is thick - effects of basal drag minimal

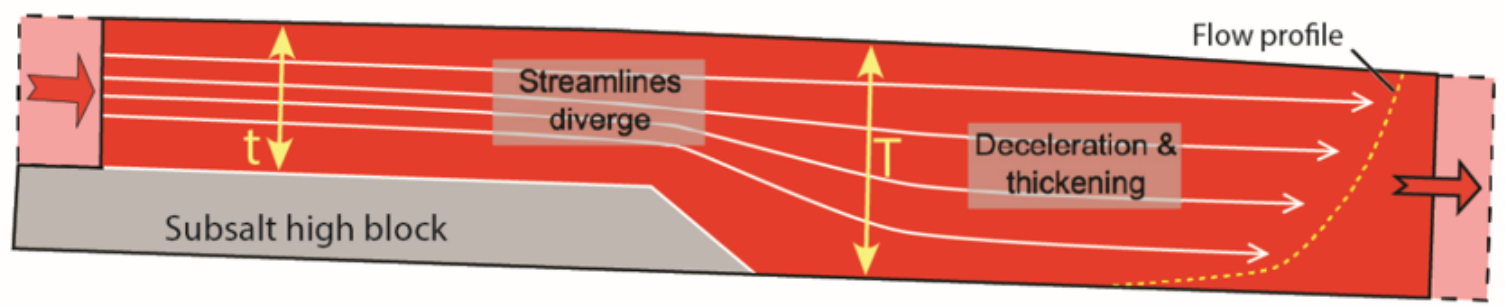

d) Low Salt on updip high is thin - salt flow retarded due to basal drag
flux
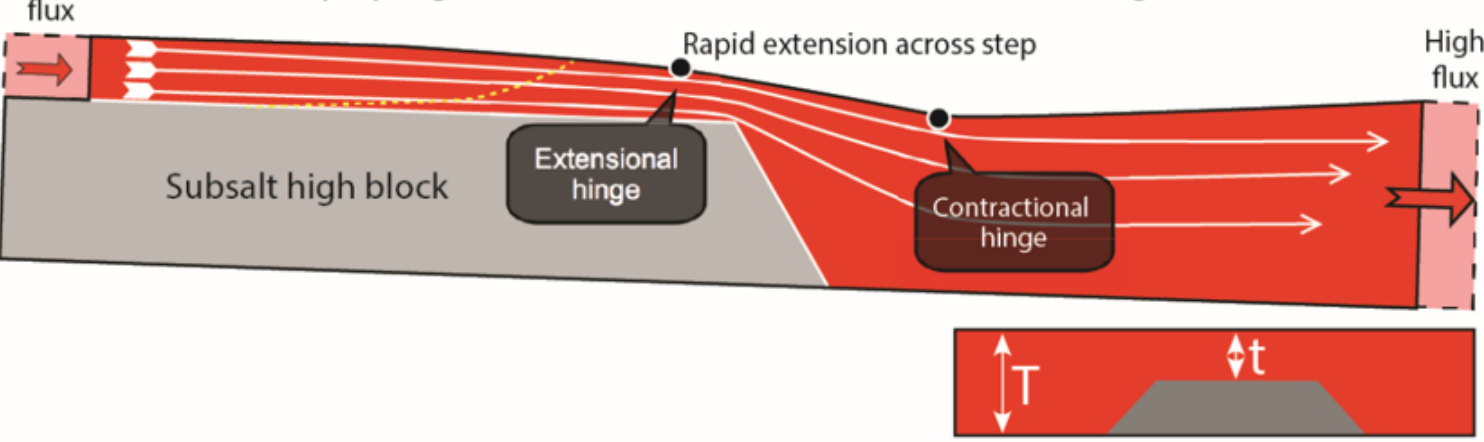

713 Figure 2: Synoptic diagram showing the complex interaction of base-salt relief with salt flow, as

714 determined from physical models. Base-salt relief causes local acceleration and deceleration

715 which in turn causes local extensional and contractional stress fields. The effect on salt flow is

716 different for thick salt cases, a) and c), compared to thin salt cases, b) and d) respectively. Note

717 that these stress fields may also vary through time. From Dooley et al. (2017). 

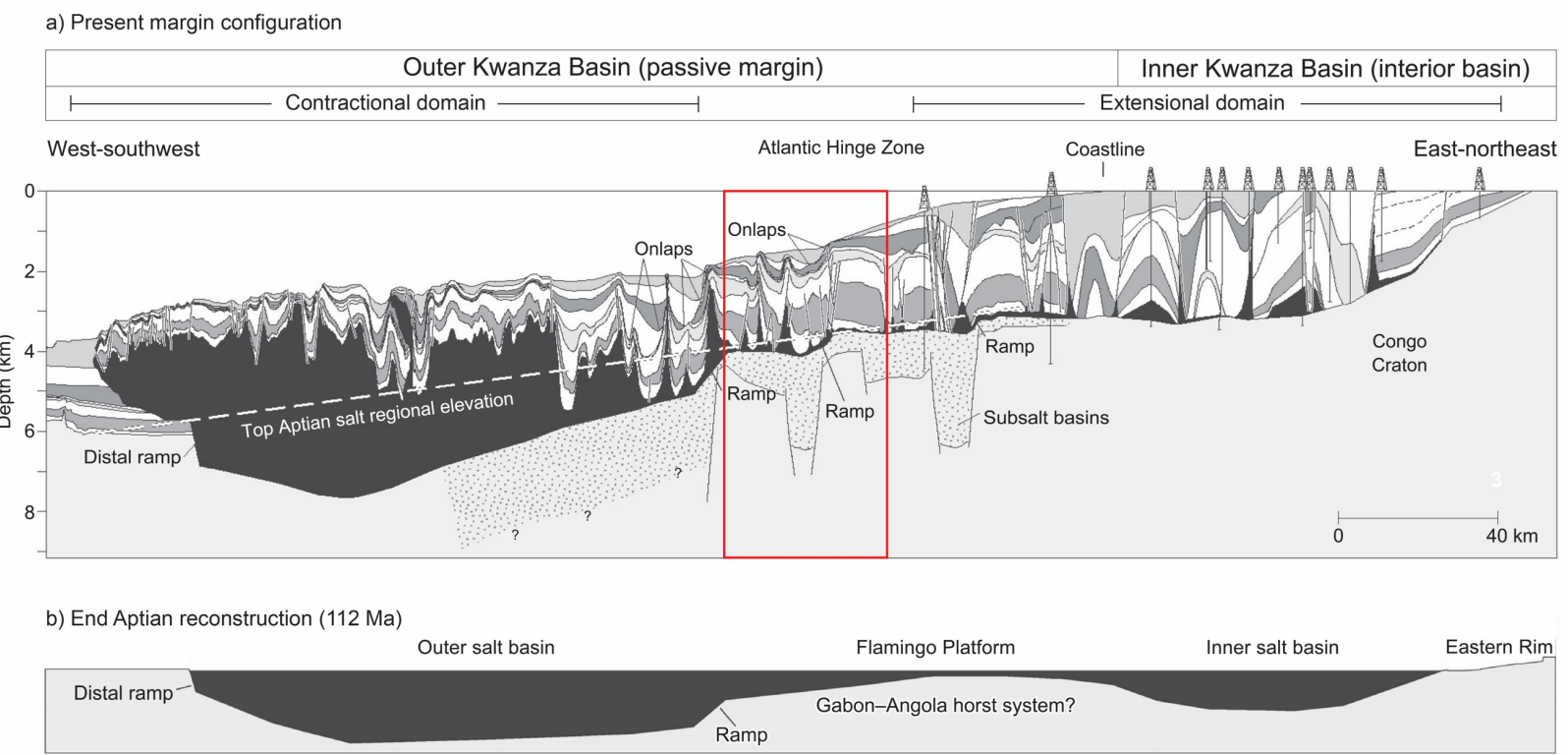

Figure 3: a) Regional line showing present day configuration of the Angolan margin from shelf to distal salt nappe. Note the presence of several ramps on the base-salt surface. Location of line shown in Figure 4. Red box highlights approximate position of dataset used in this study. b) End Aptian reconstruction showing initial division of Inner and Outer salt basins. Modified from Hudec and Jackson (2004).

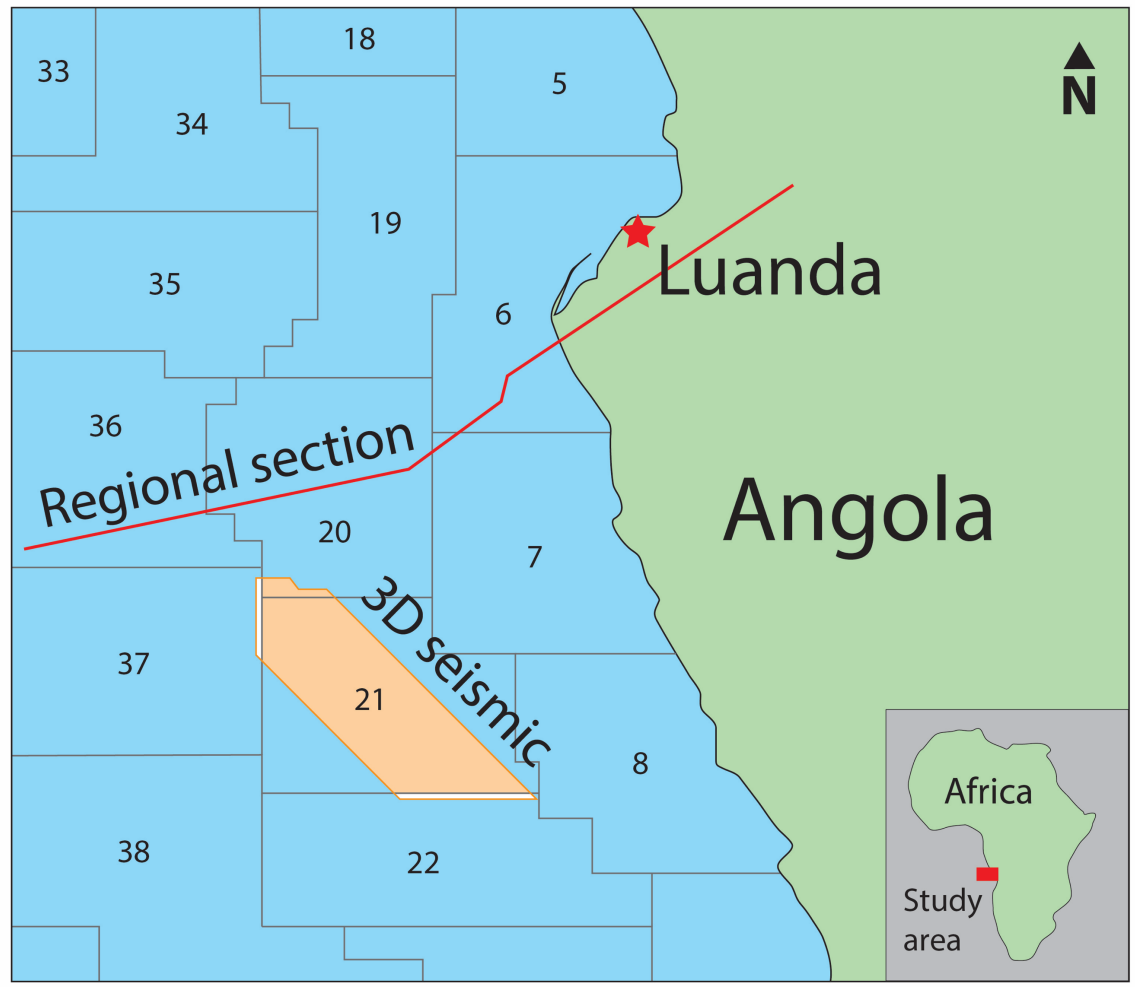

723 Figure 4: Regional map showing location of 3D dataset used in this study (orange) and regional 724 line (see Figure 3). Dataset covers Licensing Block 21 of the offshore Angolan margin. 
a) Base Salt

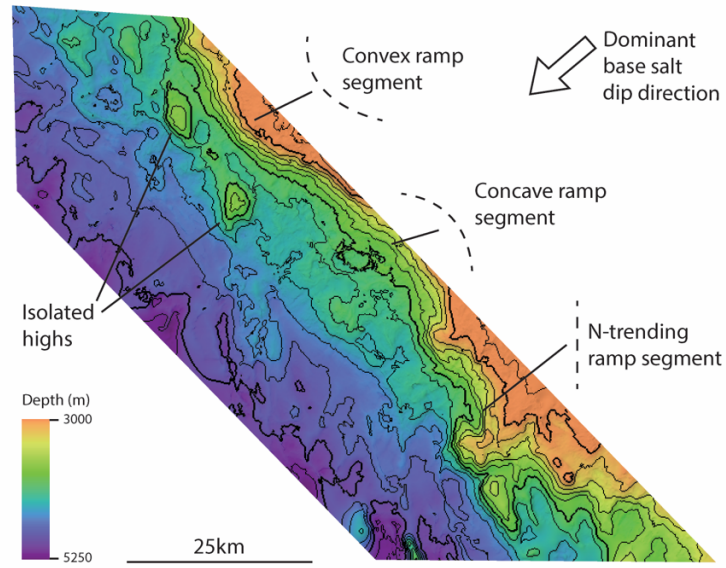

b) Salt Isopach

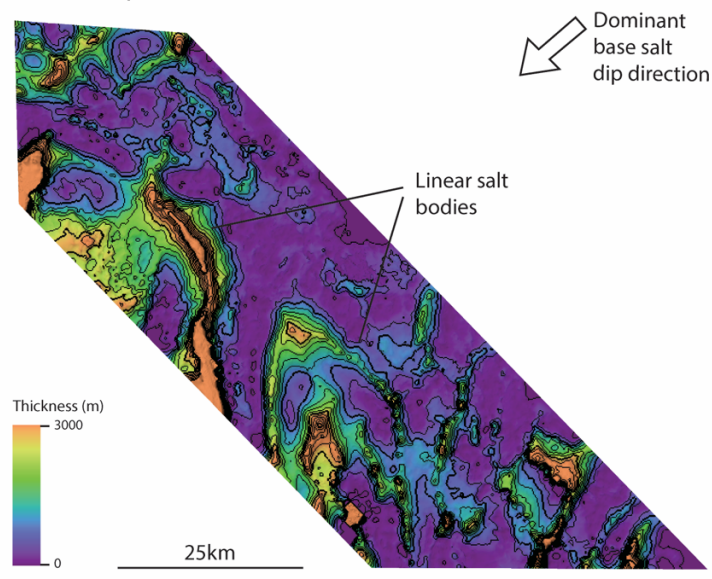

c) Salt Structures

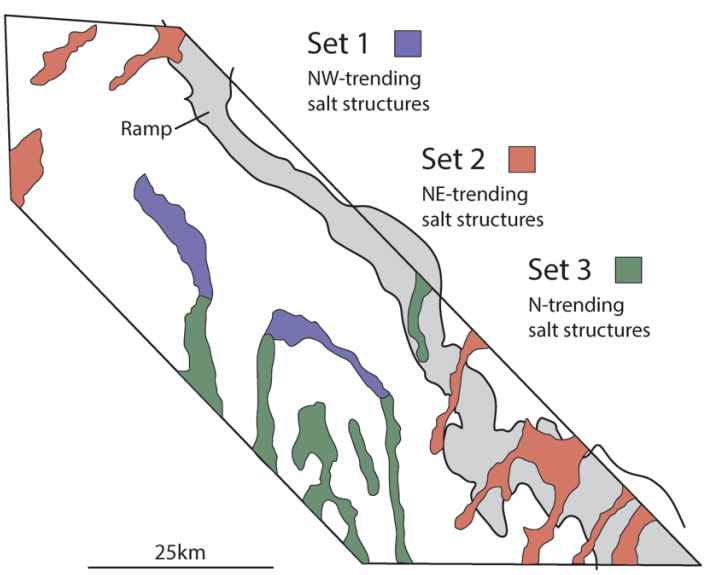

Figure 5: a) Depth map of base-salt surface showing dominant dip to the SW. Ramp runs across updip edge of the dataset, broadly sub-parallel to margin but with variable geometry along strike. b) Salt isopach map. Areas of increased thickness correspond to location of salt structures. Areas of minimal thickness show where salt is close to welding. c) Schematic distribution of salt structures across the study area, dividing the structures into three broad sets characterised by their orientation and structural style. Shaded area shows location of base-salt ramp. Seismic data supplied by CGG. 


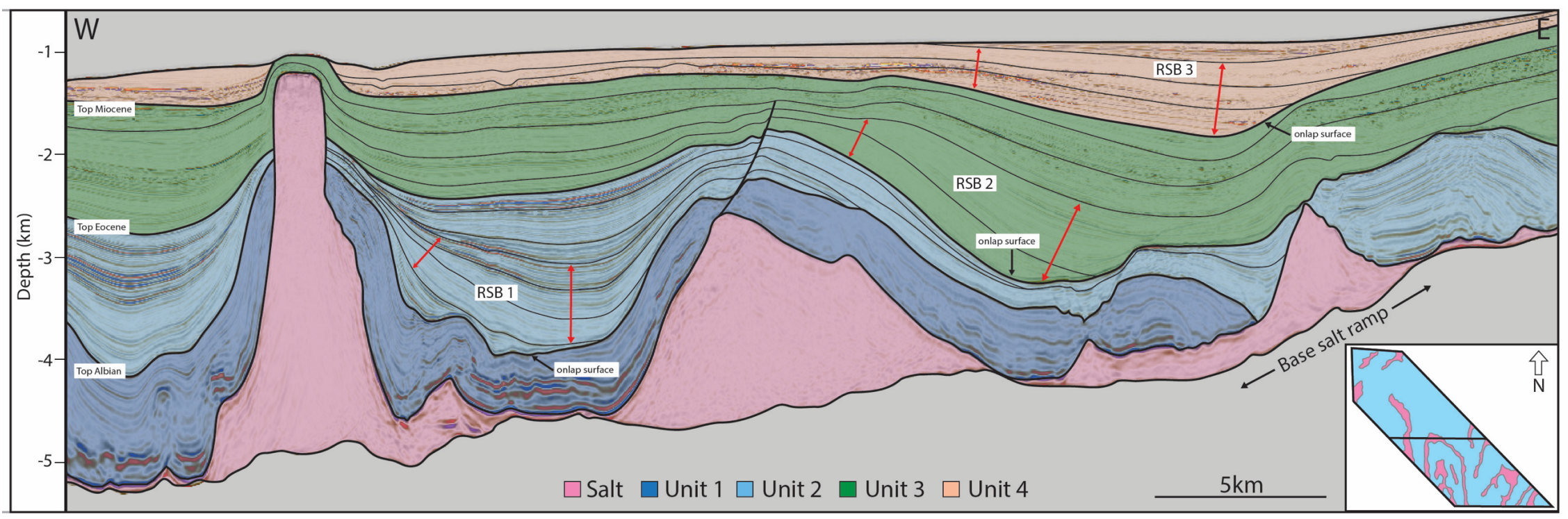

Figure 6: Representative seismic geosection showing series of salt structures (see inset map for location). Key interpreted units in the overburden (1-4) and approximate ages of key surfaces (Top Albian, Top Eocene, Top Miocene). Stacked ramp syncline basins (RSB1, RSB2, RSB3) and location of updip base-salt ramp. Seismic data supplied by CGG. 


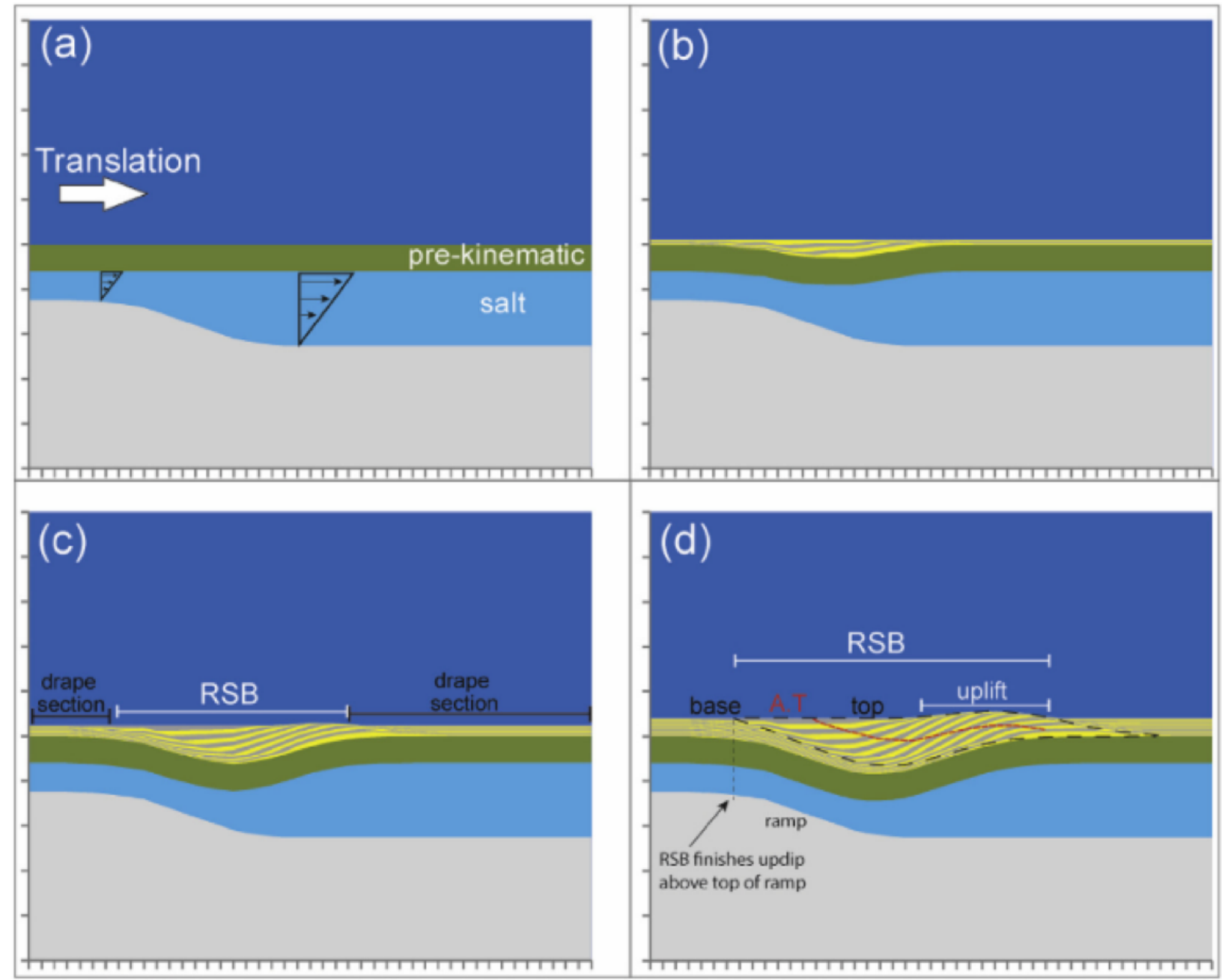

733 Figure 7: Numerical model showing incremental development of ramp syncline basin during 734 basinward translation. a) Isopachous pre-kinematic strata prior to translation. b) Imbalance of 735 salt flux creates accommodation space above ramp which fills which growth strata thickening 736 into ramp. c) Early growth strata are rotated and moved downdip as translation continues. d) 737 Fully developed ramp syncline basin showing monoclinal geometry of growth strata, basal 738 onlap surface and distal uplift. From Pichel et al. (2018). 

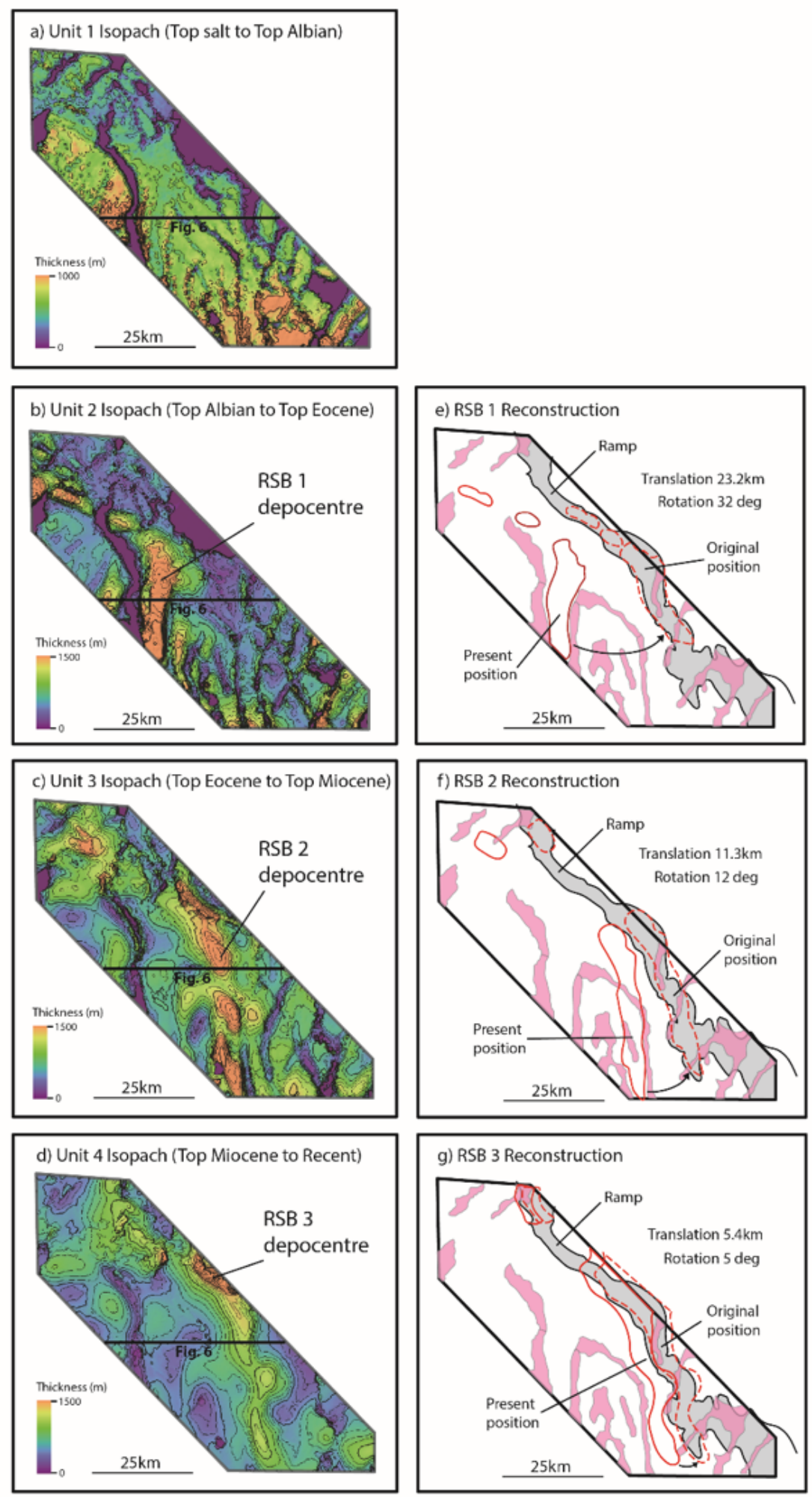

739 Figure 8: a-d) Isopach maps for key units (see Figure 6). Thick, linear depocentres correspond to 740 ramp syncline basins. Location of Figure 6 section is shown for reference. e-g) Reconstructed 741 positions of ramp syncline basins above the causal base-salt ramp, allowing translation and 742 rotation to be quantified through time. Seismic data supplied by CGG. 


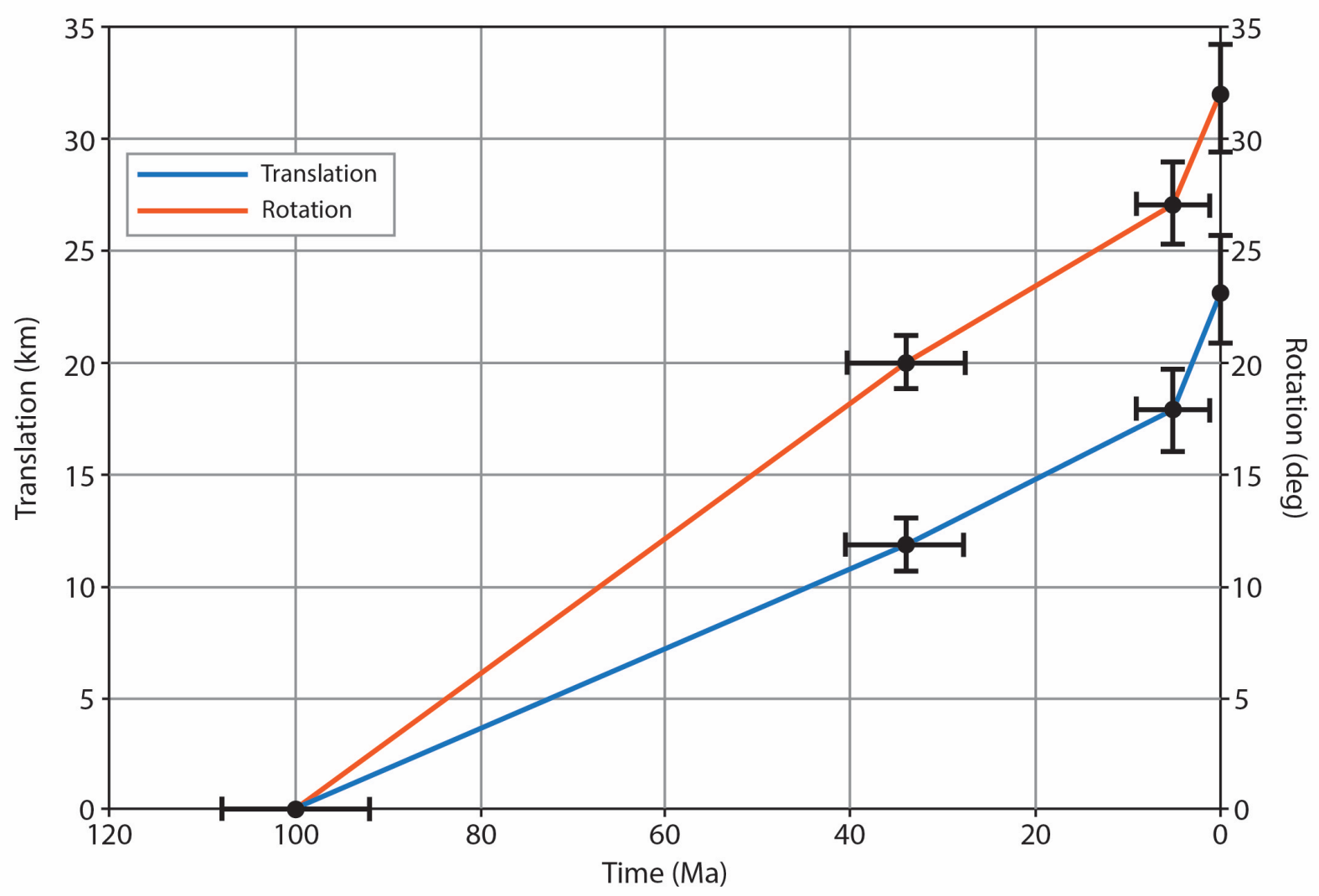

743 Figure 9: Graph showing translation and rotation through time since end Albian, as derived 744 from ramp syncline basins (see Table 1). 
a)

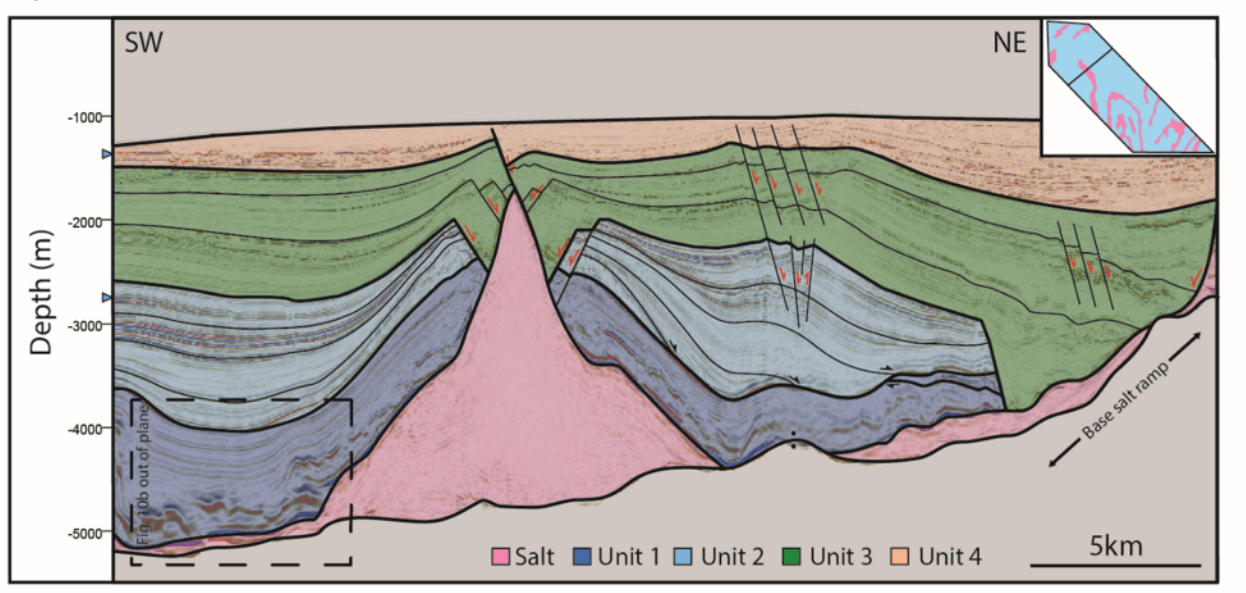

b)

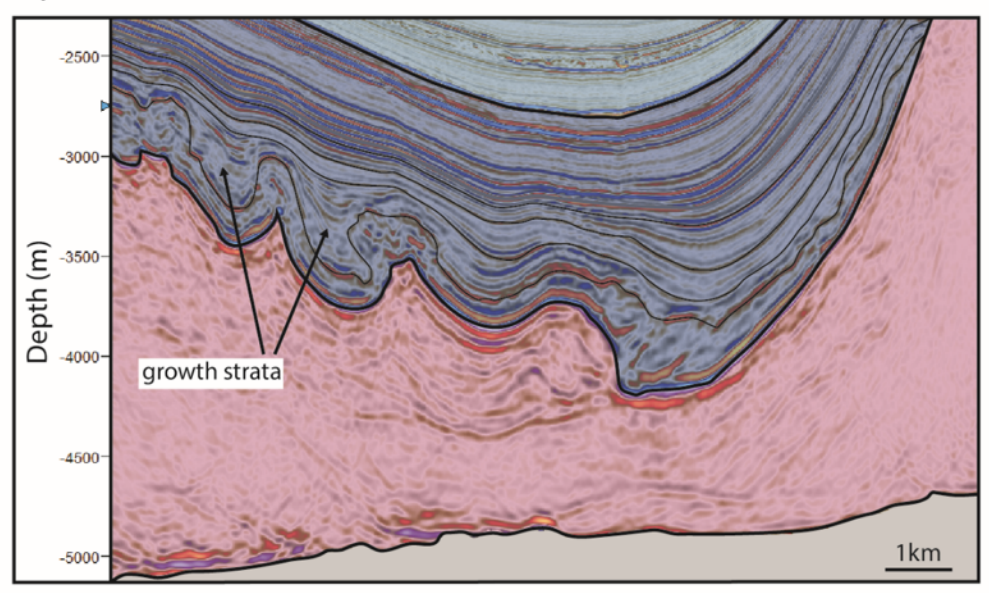

745

746

747

Figure 10: a) Seismic geosection through Set 1 salt wall (see inset map for location). Note the triangular geometry, inward-dipping crestal normal faults and updip base-salt ramp. b) Enlarged section showing buckle folds and growth strata on the flank of the salt wall at base of Unit 1 (out of plane of section shown in Figure 10a). Seismic data supplied by CGG. 
a)

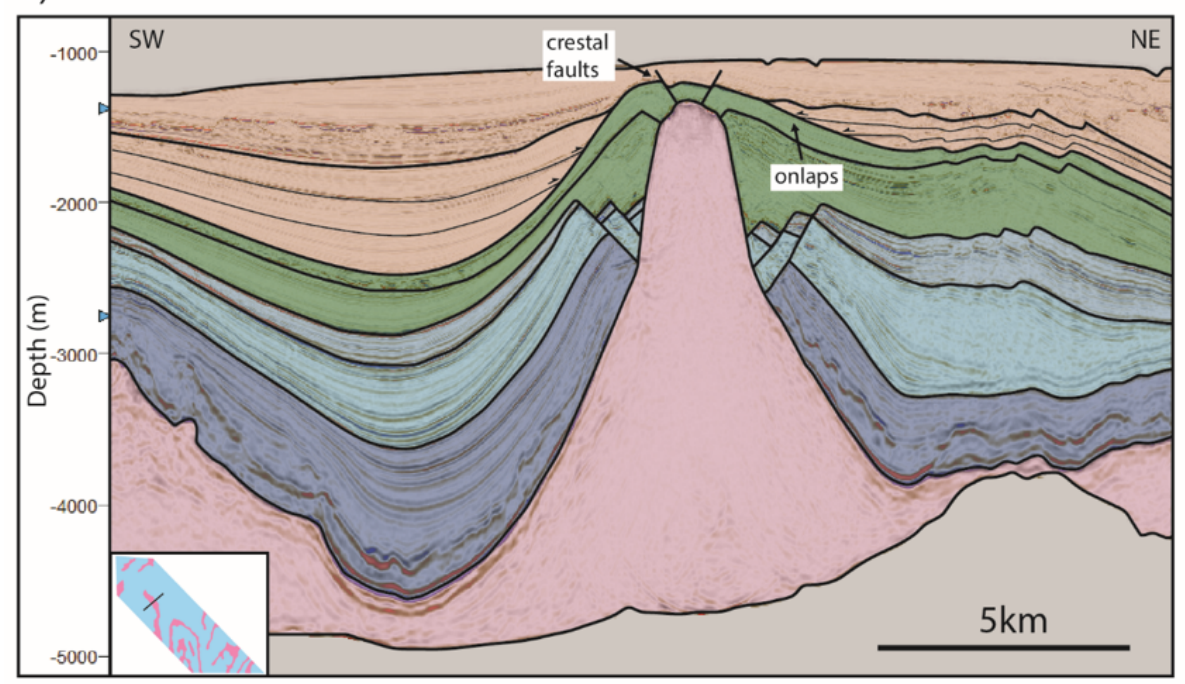

b)

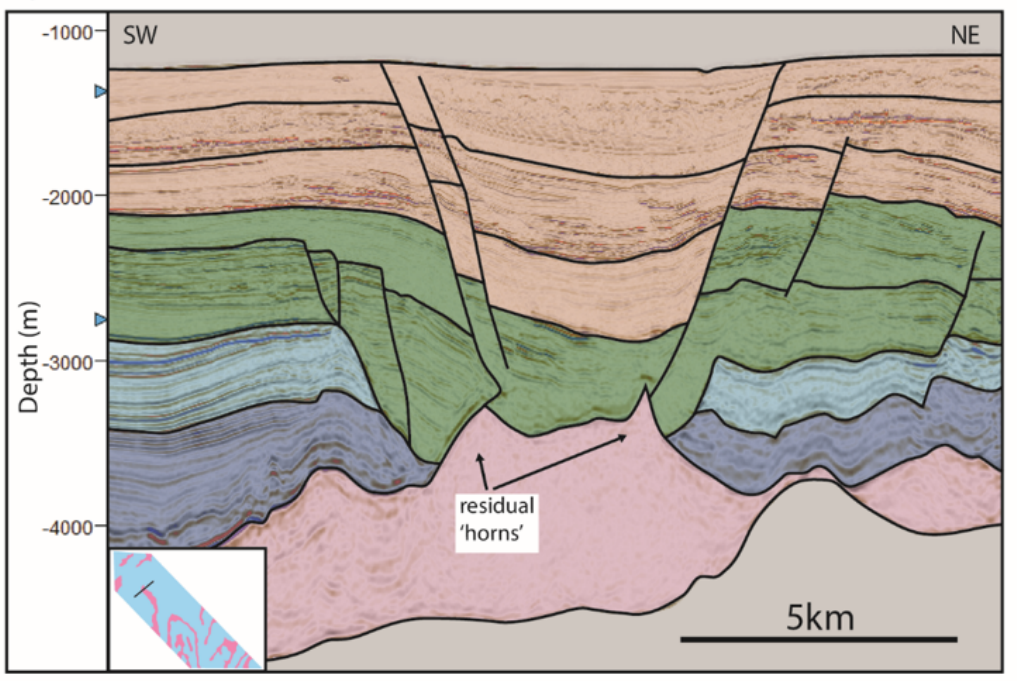

Figure 11 - a) Seismic geosecton through central Set 1 salt wall showing characteristics indicative of active rise. b) Seismic geosection through end of Set 1 salt wall showing characteristics indicative of diapir collapse. Locations shown in inset maps. Seismic data supplied by CGG. 

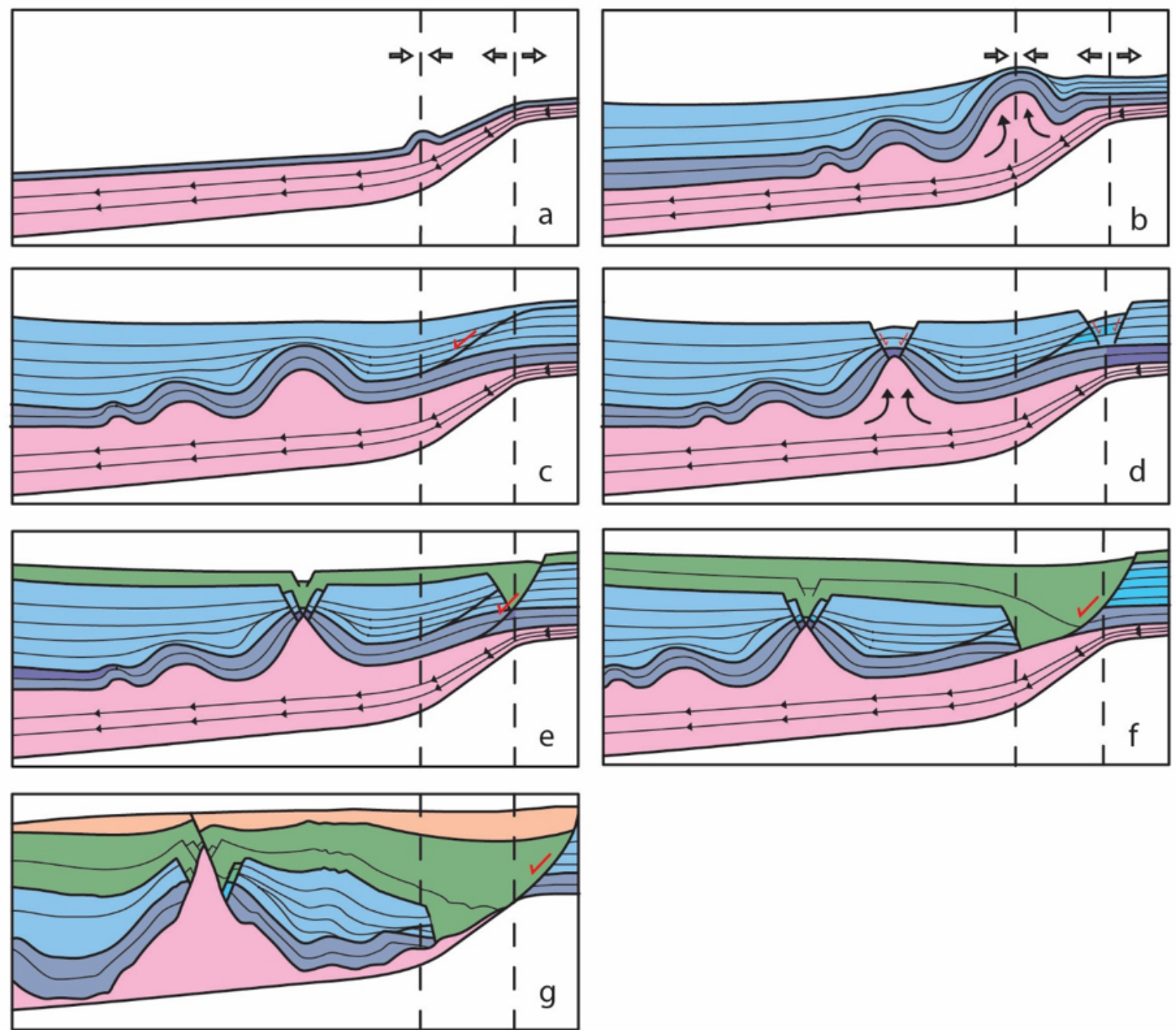

751 Figure 12: Schematic evolution of the Set 1 salt structures. Location of each schematic time step

752 shown in Figure 17. a) Initial contraction as salt decelerates at base of ramp. b) Overburden

753 thickening and sediment loading drives growth of salt-cored anticline as translation continue. c)

754 Overburden strengthens and normal fault develops above ramp. d) Local extension as grabens

755 open at points of overburden weakness - top of the ramp and crest of the salt-cored anticline.

756 e) Syn-kinematic sediments thicken over crest as reactive rise drives further growth of salt wall.

757 Normal fault above ramp grows and detaches into salt. f) Normal fault facilitates continued

758 downdip translation of the salt and overburden. e) Present day geometry. 
a)

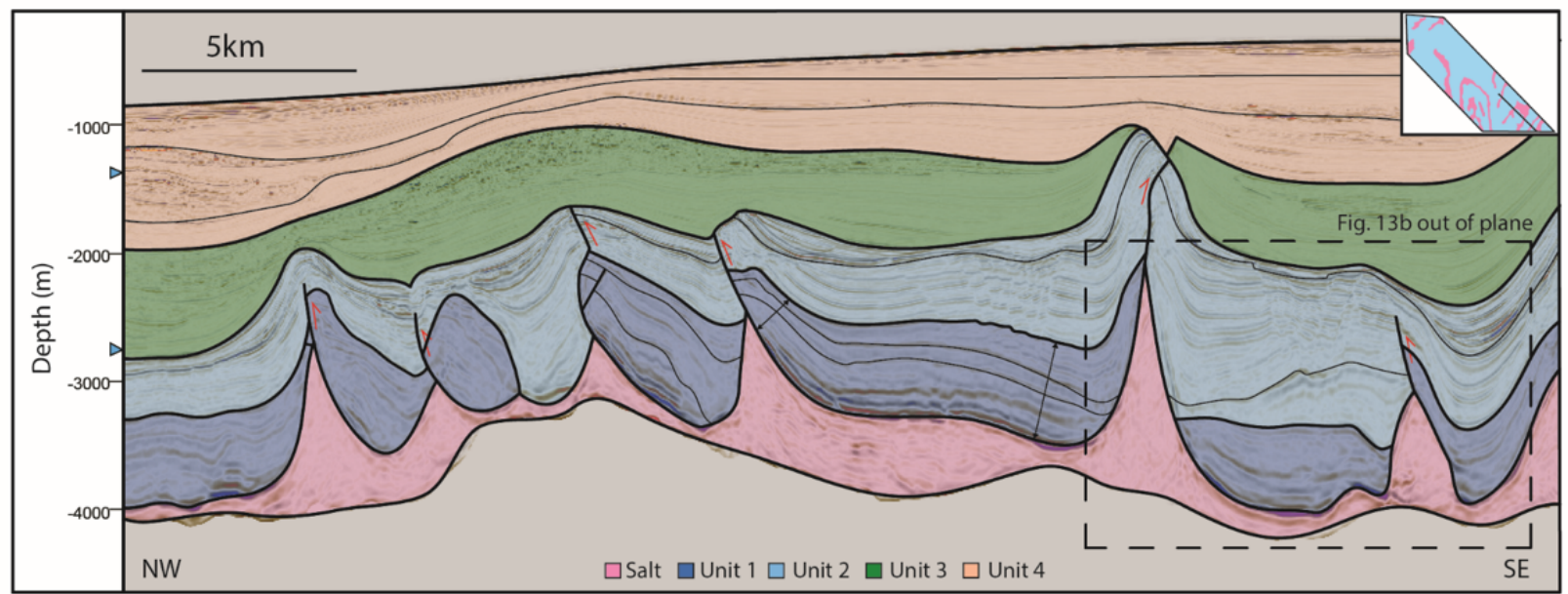

b)

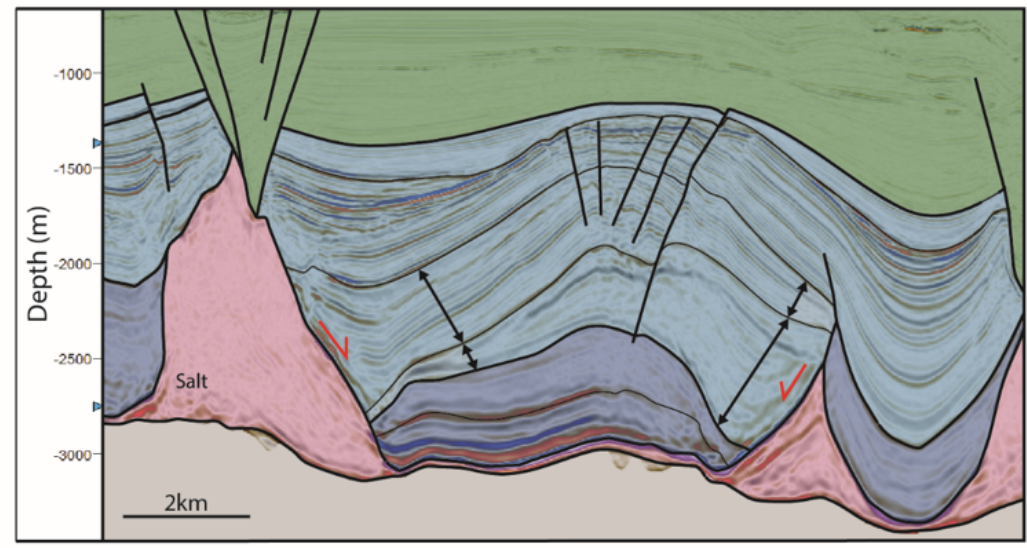

759 Figure 13: a) Seismic geosection through Set 2 salt structures (see inset map for location; note 760 that as this section is taken perpendicular to the Set 2 salt walls, the net flow direction of salt is 761 out of the page, towards the viewer). Note the rafts of Unit 1 and the thrust faults associated 762 with each salt wall. b) Enlarged section showing turtle anticline structure (out of plane of 763 section shown in Figure 13a). Seismic data supplied by CGG. 

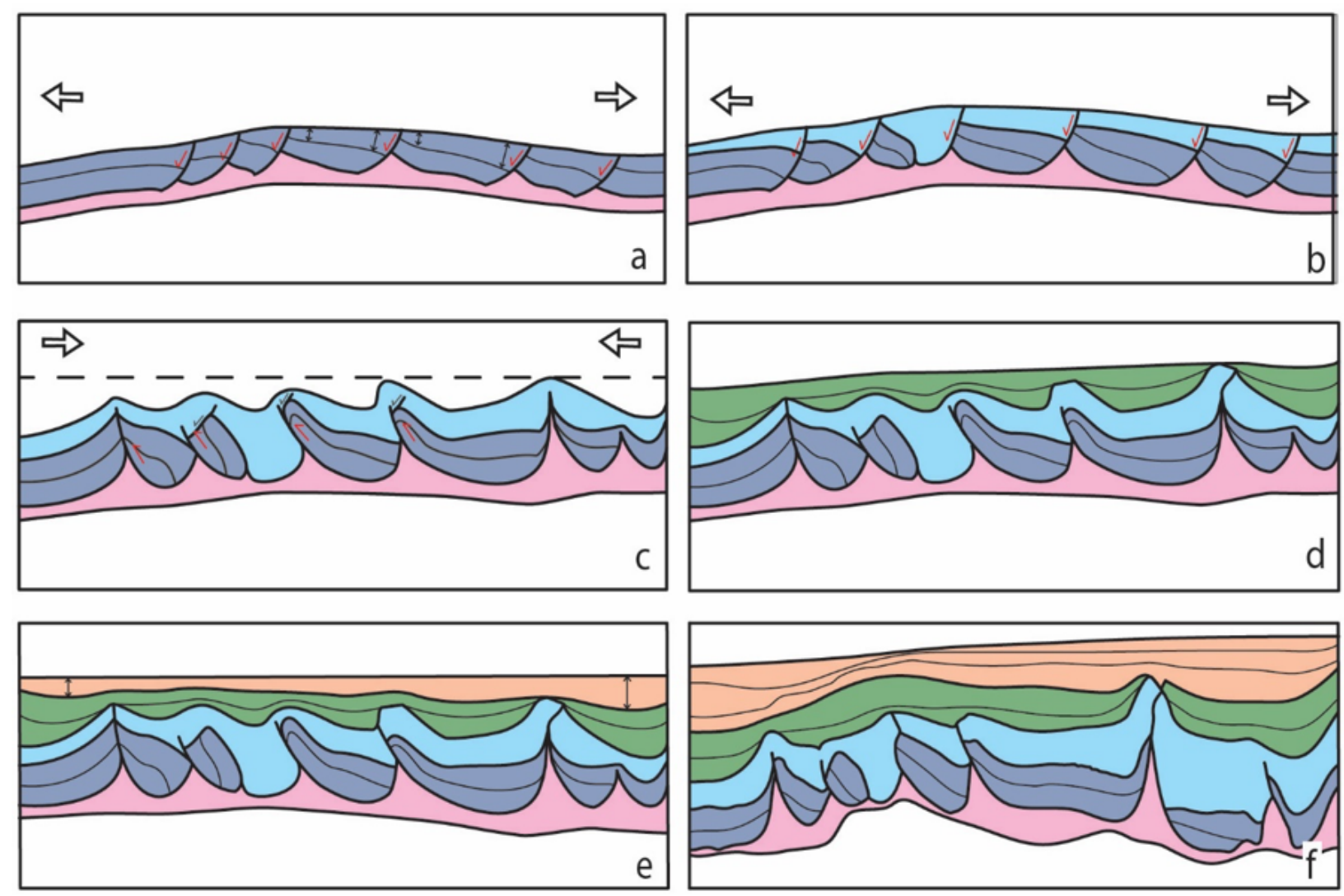

Figure 14: Schematic evolution of the Set 2 salt structures. Locations of each schematic time step shown in Figure 17. a) Early development of extensional salt rollers and associated growth strata. Normal faults detach in salt and dip to the west. b) Continued extension leads to rafting (turtle anticline develops out of plane). c) Onset of contraction exploiting weak salt rollers and causing rafts to thrust over each other. Local erosion of uplifted strata. d) Sediments onlap residual highs and salt walls become buried. e) Inactivity of salt structures and continued burial. Growth strata shows asymmetric subsidence as downdip translation progresses. f) Present day 771 geometry. 


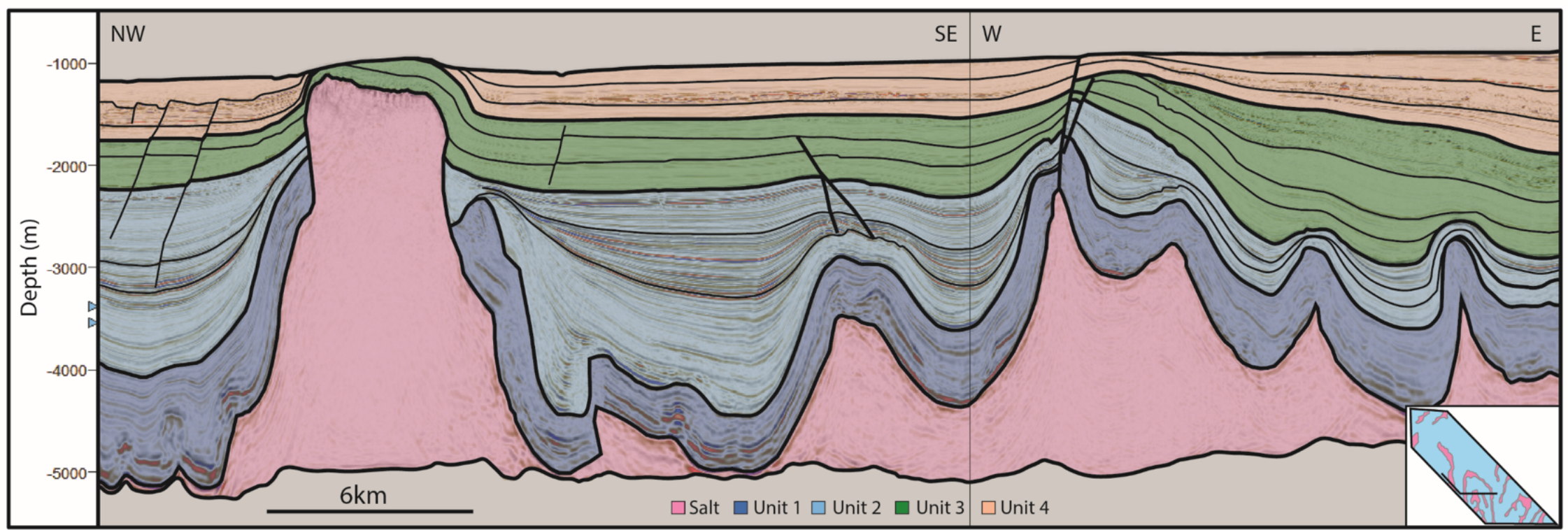

Figure 15: Seismic geosection through Set 3 salt structures (see inset map for location; note that line bends in order to cross a larger

773 Set 3 salt wall, the only one to pierce the overburden). Note the isopachous nature of Unit 1 and prominent growth strata of Unit 2.

774 Seismic data supplied by CGG. 

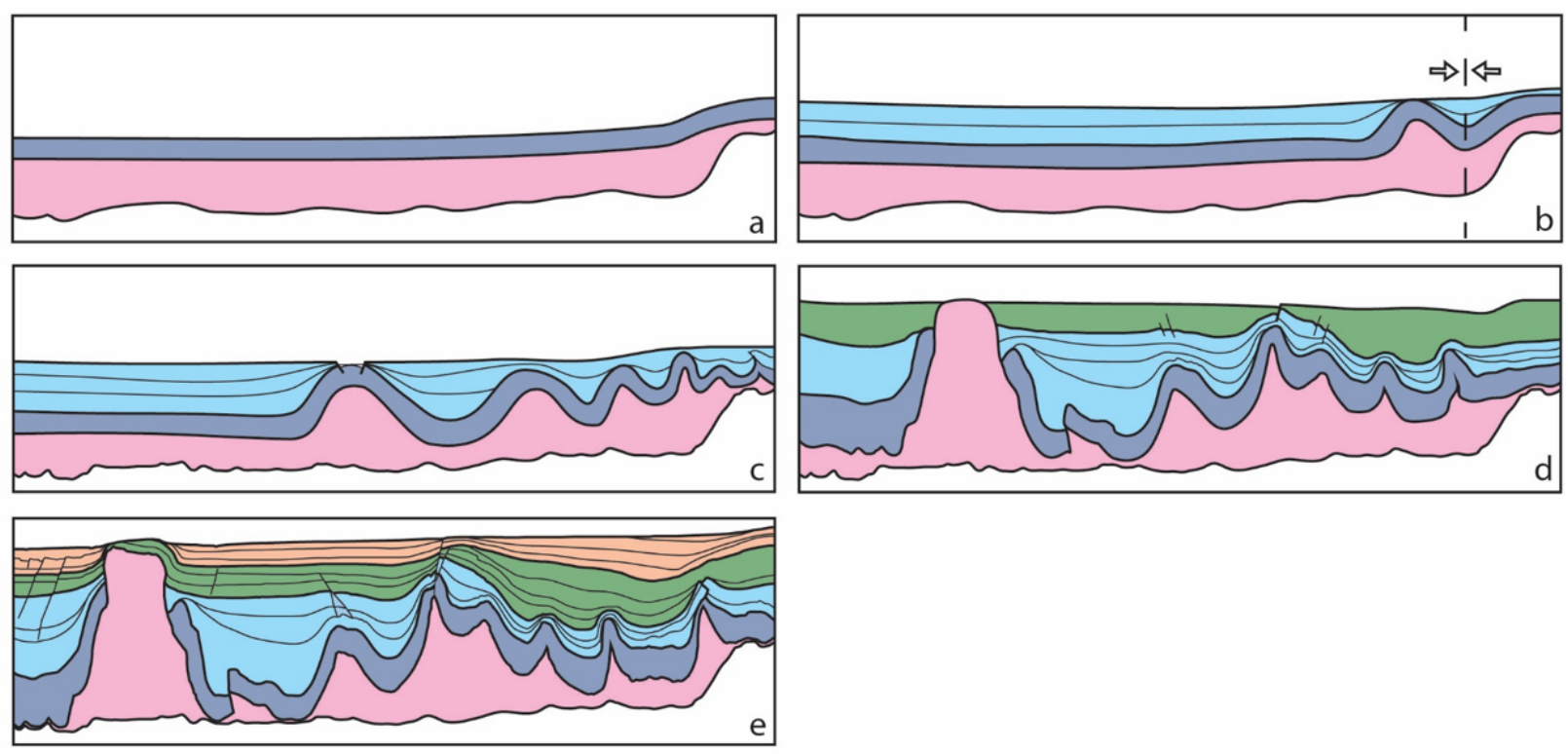

775 Figure 16: Schematic evolution of the Set 3 salt structures. Locations of each schematic time 776 step shown in Figure 17. a) Pre-kinematic, isopachous deposition of Unit 1. b) Rapid growth of 777 salt-cored anticlines. c) Salt-cored anticlines translated away from base-salt ramp and amplified 778 by sediment loading. New ones develop in their place. d) Growth of anticlines slows and most 779 become buried. The buoyancy associated with the oldest and largest anticline is enough to 780 generate active rise and pierce the overburden. e) Present day geometry. 

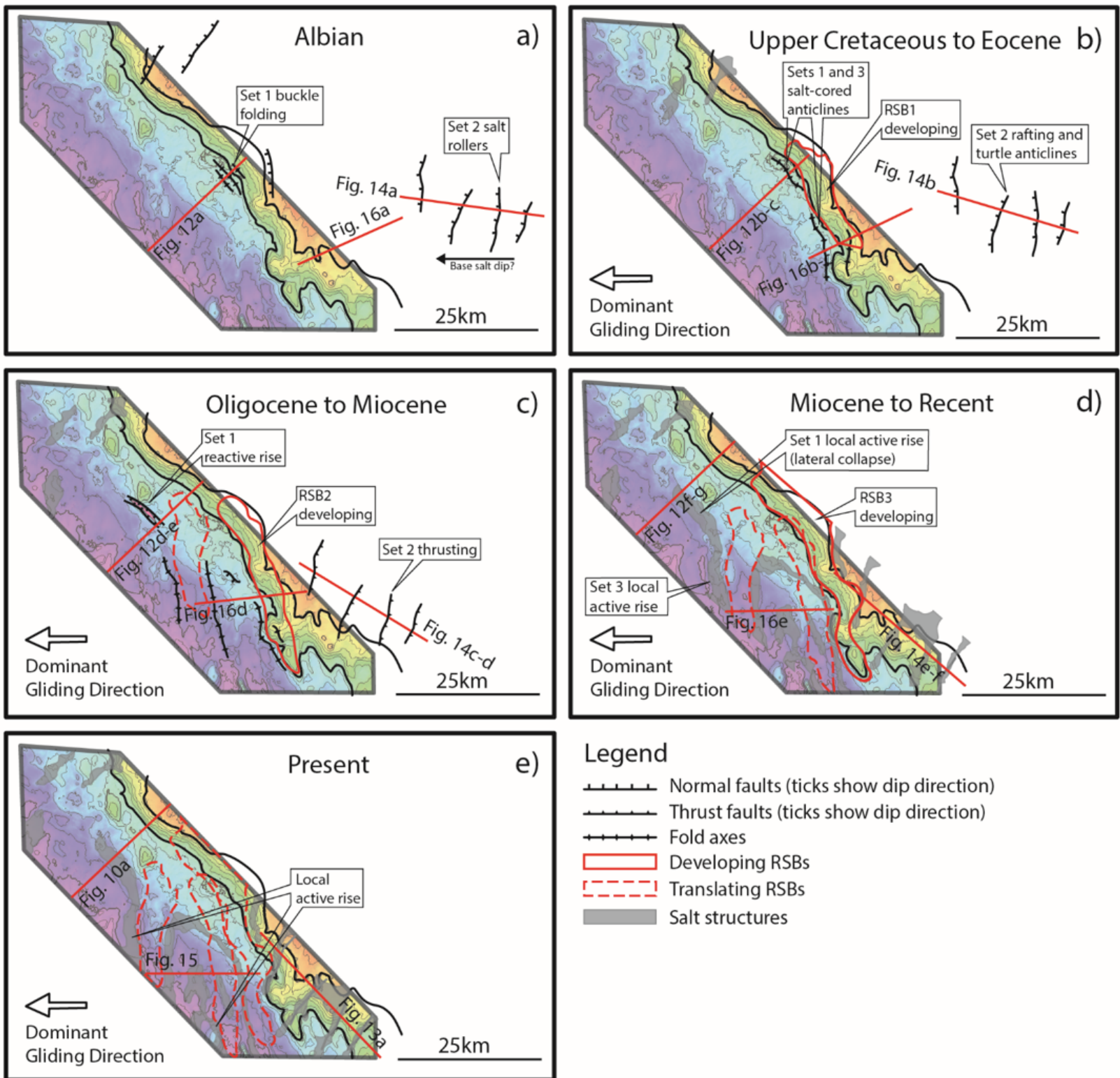

\section{Legend}

ــــ Normal faults (ticks show dip direction)

ــــ Thrust faults (ticks show dip direction)

$\longleftrightarrow$ Fold axes

$\square$ Developing RSBs

r--ー-1 Translating RSBs

Salt structures

781 Figure 17: Reconstructed salt structure evolution through time using reconstructed positions of 782 ramp syncline basins (see Figure 8). Shows active structures and development of RSBs at each 783 time step, overlaid on map of base-salt relief. See Figures 12, 14 and 16 for schematic structural 784 evolutions. 